
5 Wenli Chen $^{1 *}$, Peng Cai ${ }^{1,2}$, Qiaoyun Huang ${ }^{1,2^{*}}$

6 University, Wuhan 430070, China Agricultural University, Wuhan 430070, China of China, Hefei 230029, China Academy of Sciences, Beijing 100039, China

\section{Supporting information summary:}

Number of pages: 29

Number of figures: 13

Number of tables: 6

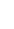
22 23 24 25 26 27 (1)

Supplementary information

\title{
Size-Dependent Bacterial Toxicity of Hematite Particles
}

Chenchen $\mathrm{Qu}^{1,2}$, Shufang Qian ${ }^{1}$, Liang Chen ${ }^{3}$, Yong Guan ${ }^{3}$, Lei Zheng ${ }^{4}$, Shuhu Liu ${ }^{4}$,

${ }^{1}$ State Key Laboratory of Agricultural Microbiology, Huazhong Agricultural

${ }^{2}$ Hubei Key Laboratory of Soil Environment and Pollution Remediation, Huazhong

${ }^{3}$ National Synchrotron Radiation Laboratory, University of Science and Technology

${ }^{4}$ Beijing Synchrotron Radiation Facility, Institute of High Energy Physics, Chinese

*E-mail: qyhuang@ mail.hzau.edu.cn, wlchen@mail.hzau.edu.cn. 


\section{Supplementary Methods:}

\section{Bacterial Cultivation.}

Two soil bacterial strains $\mathrm{G}^{-}$Pseudomonas putida KT2440 and $\mathrm{G}^{+}$Bacillus subtilis 168 were selected in this study. Their isolates were obtained from China Center for Type Culture Collection. They were stored on Luria-Bertani (LB) agar plates at $4{ }^{\circ} \mathrm{C}$. Single colonies of each strain were picked up and first cultured aerobically in $5 \mathrm{~mL}$ of $\mathrm{M} 9$ medium on a rotary shaker at $28^{\circ} \mathrm{C}$ for $24 \mathrm{~h}$. This initial culture was then transferred to $200 \mathrm{~mL}$ of M9 medium and grown aerobically until mid-exponential growth phase. Due to the slow growth of B. subtilis in M9 minimal medium, the large amount of cells for in-situ FTIR were cultured in LB medium for both bacterial strains. The cells were harvested by centrifugation for $5 \mathrm{~min}$ at $4100 \mathrm{~g}$ and $4{ }^{\circ} \mathrm{C}$. The growth medium was decanted, and the pellet was rinsed three times by $0.9 \% \mathrm{NaCl}$. After the final rinse, the resulting pellets were resuspended in $0.9 \% \mathrm{NaCl}$. The obtained bacterial suspensions were quantitated by $\mathrm{OD}_{600 \mathrm{~nm}}$. The $\mathrm{M} 9$ medium (pH 7.0) contains $48 \mathrm{mM} \mathrm{Na}_{2} \mathrm{HPO}_{4}, 22 \mathrm{mM} \mathrm{KH}_{2} \mathrm{PO}_{4}, 9 \mathrm{mM} \mathrm{NaCl}, 19 \mathrm{mM} \mathrm{NH} \mathrm{Cl}_{4}, 2$ $\mathrm{mM} \mathrm{MgSO}_{4}, 0.1 \mathrm{mM} \mathrm{CaCl}_{2}$, and $8 \mathrm{mM}$ glucose. ${ }^{1}$ Analytical reagent grade chemicals purchased from Sinopharm Chemical Reagent Co., Ltd were used throughout the study. Water was Milli-Q reagent grade.

\section{Hematite Preparation}

The largest hematite was purchased from Sigma-Aldrich $(\sim 1 \mu \mathrm{m})$ and used without further treatment. The $10 \mathrm{~nm}$ and $80 \mathrm{~nm}$ hematite samples were synthesized in this study following the instructions from Schwertmann and Cornell. ${ }^{2}$ Briefly, the $10 \mathrm{~nm}$ hematite nanoparticles were synthesized by slowly dripping $60 \mathrm{~mL}$ of $1 \mathrm{M}$ $\mathrm{Fe}\left(\mathrm{NO}_{3}\right)_{3}$ solution into $750 \mathrm{~mL}$ boiling water on a hot plate. To synthesize the $80 \mathrm{~nm}$ hematite, a total of $40 \mathrm{~g} \mathrm{Fe}\left(\mathrm{NO}_{3}\right)_{3} \cdot 9 \mathrm{H}_{2} \mathrm{O}$ was dissolved in $500 \mathrm{~mL}$ deionized water and precipitate with $300 \mathrm{~mL} 1 \mathrm{M} \mathrm{KOH}$ preheated at $90{ }^{\circ} \mathrm{C}$. Then, $50 \mathrm{~mL} 1 \mathrm{M}$ $\mathrm{NaHCO}_{3}$ was add and hold the suspension $(\mathrm{pH}=8-8.5)$ in a closed polyethylene flask at $90{ }^{\circ} \mathrm{C}$ for $48 \mathrm{~h}$. The suspensions were dialyzed against MilliQ water until the conductivity of the dialysis water $<15 \mu \mathrm{S} / \mathrm{cm}$. Precipitates were recovered by 
centrifuging at $12,000 \mathrm{~g}$ for $10 \mathrm{~min}$ and the powders were dried and stored at room temperature.

\section{Characterization of Materials}

X-Ray diffraction measurements on hematite powder were carried out using a Bruker D8 Advance X-ray diffractometer equipped with a LynxEye detector, using Ni-filtered $\mathrm{Cu} \mathrm{Ka}$ radiation. The diffractometer was operated at a tube voltage of $40 \mathrm{kV}$ and a tube current of $40 \mathrm{~mA}$. A step size of $0.02^{\circ}$ with a scanning rate of $2^{\circ} \min ^{-1}$ was used for the measurement. The specific surface area was determined using the BET $\mathrm{N}_{2}$ adsorption method (Quantachrome Autosorb-1, JEDL-6390/LV). The hydrodynamic radius of hematite was determined by dynamic light scattering (Zetasizer Nano ZEN 3600, Malvern, UK). Before measurement, the hematite suspensions in $\mathrm{pH} 5 \mathrm{HNO}_{3}$ solution were disaggregated using a sonic dismembrator (Branson Sonifier 450) at $\sim 160 \mathrm{~W}$ for $10 \mathrm{~min}$. The charge of the hematite and bacterial cells was measured by a zeta potential analyzer in $0.15 \mathrm{M} \mathrm{NaCl}$ suspensions at $\mathrm{pH} 7$ (Zetasizer Nano ZEN 3600, Malvern, UK). The morphology of hematite NPs were determined using a field emission transmission electron microscope (TEM, JEOL JEM-2100F) operated at 200 $\mathrm{kV}$.

The contact angles were measured using the static sessile drop method on a goniometer (Drop Shape Analysis System, DSA25S, Kruss GmbH, Hamburg, Germany). For bacteria, a defined amount of bacterial suspension in $0.15 \mathrm{M} \mathrm{NaCl}$ was vacuum-filtered through $0.45 \mu \mathrm{m}$ pore size synthetic fabric filters $(50 \mathrm{~mm}$ in diameter, Xinya Shanghai) to form a uniform cell layer. ${ }^{3}$ The filters containing the bacterial layers were then mounted on glass slides and air-dried in a desiccator for approximately $30 \mathrm{~min}$. The mineral films were prepared through evaporation of 0.5 $\mathrm{mL}$ finely dispersed $1 \mathrm{mg} / \mathrm{mL}$ mineral suspensions on $15 \mathrm{~mm}$ diameter microscope cover glass slides. All determinations were conducted in triplicates using three different liquids (water, diiodomethane and formamide). The defects of iron oxide surface and $\mathrm{Fe}(\mathrm{II}) / \mathrm{Fe}(\mathrm{III})$ ions can produce ROS in the Fenton reaction. The hematite samples were able to release highly uncoordinated $\mathrm{Fe}^{2+}$ ions located most probably at the edge or corner positions, and were prone to be removed. ${ }^{4}$ The amount of $\mathrm{Fe}^{2+}$ ions 
on hematite surface was evaluated by suspending hematite $(1 \mathrm{mg} / \mathrm{mL})$ in a $0.15 \mathrm{M}$ $\mathrm{NaCl}$ solution containing $1 \mathrm{mM}$ ferrozine at $\mathrm{pH} 4.5$ and $37^{\circ} \mathrm{C}$. The suspensions were continuously shaken for 4 days and the $\mathrm{Fe}^{2+}$-ferrozine complex was determined by measuring the absorbance at $562 \mathrm{~nm}$ on a dual beam spectrophotometer (AOE Instruments A580, Shanghai, China). ${ }^{4}$ The total amount of dissolved Fe ions in the presence of bacteria was measured by mixing equal volumes of $0.5 \mathrm{~g} / \mathrm{L}$ hematite and cell suspensions $\left(\mathrm{OD}_{600 \mathrm{~nm}}=1\right)$. The composites were incubated in a shaker at $28^{\circ} \mathrm{C}$ for $24 \mathrm{~h}$. A total of $3 \mathrm{~mL}$ suspension was taken and rinsed in $4 \mathrm{~mL} 0.15 \mathrm{M} \mathrm{NaCl}$ containing $50 \mathrm{mM}$ EDTA and $100 \mathrm{mM}$ oxalic acid for $30 \mathrm{~min}$ at $\mathrm{pH}$ 6.95. This oxalate-EDTA solution removes metals from the exterior cell envelope without causing cell lysis. ${ }^{5,6}$ The suspension was centrifuged, and $1 \mathrm{~mL}$ of the supernatant was mixed with $100 \mu \mathrm{L}$ of $100 \mathrm{~g} / \mathrm{L}$ hydroxylamine hydrochloride which reduces $\mathrm{Fe}(\mathrm{III})$ to $\mathrm{Fe}(\mathrm{II})$. Then, $1 \mathrm{~mL} 100 \mathrm{~g} / \mathrm{L}$ ammonium acetate buffer was added, followed by $1 \mathrm{~mL}$ of $1 \mathrm{~g} / \mathrm{L} \mathrm{1,10-phenanthroline.} \mathrm{Total} \mathrm{iron} \mathrm{was} \mathrm{detected} \mathrm{by} \mathrm{measuring} \mathrm{the} \mathrm{absorbance} \mathrm{at}$ $530 \mathrm{~nm}$ on a dual beam spectrophotometer. ${ }^{7}$

\section{Inactivation and Membrane Permeability Experiments}

The cells (optical density at $600 \mathrm{~nm}=1, \sim 5 \times 10^{8}$ cells $/ \mathrm{mL}$ ) were incubated with 0 , 20, 50, 100, 200 and $500 \mathrm{mg} / \mathrm{L}$ hematite in $0.9 \% \mathrm{NaCl}$ at $\mathrm{pH} 6.8 \pm 0.2,28{ }^{\circ} \mathrm{C}$ and 180 rpm. The same incubation conditions and concentrations for bacteria and mineral were used across this study unless otherwise stated. To minimize the aggregation of hematite particles, a 10-min ultrasonic treatment was performed immediately before mixing them with bacterial cells. After incubate for $0,1,5,10$ and $25 \mathrm{~h}$, serial dilutions of the bacterial suspensions were plated on solid Luria Bertani-agar plates and incubated overnight at $28{ }^{\circ} \mathrm{C}$; then, colonies were counted. All treatments were prepared in triplicates.

The membrane permeabilization of bacteria was also measured using a Live/Dead BacLight Bacterial Viability Kit. To prepare samples for fluorescent observation, the mineral suspensions were deposited on glass slide and formed flat mineral surfaces, which benefits the focus under microscope. The glass slides were immersed in bacteria suspensions (optical density at $600 \mathrm{~nm}=0.4$ ) for approximately 5 
min to allow cell adhesion on hematite films. The glass slides were then rinsed thoroughly and immersed in $0.9 \% \mathrm{NaCl}$ solution for $0,3,5,10$ and $25-\mathrm{h}$ before staining and observation. The Live/Dead BacLight Bacterial Viability kit includes the SYTO-9 green-fluorescent nucleic acid stain and the propidium iodide red-fluorescent nucleic acid stain. The SYTO-9 stain generally labels all bacteria (those with intact membranes and those with damaged membranes), whereas propidium iodide penetrates only bacteria with damaged membranes. Using a mixture of the SYTO-9 and propidium iodide stains, bacteria with intact cell membranes will be stained green, whereas bacteria with damaged membranes will be stained red. To segment all cells from the background the fluorescent images were converted in a RGB-image stack using software ImageJ (http://imagej.nih.gov/ij/). Afterwards automated thresholding was used separately for both the red and green channel. Both images were combined and the cells were registered using the "Particle Analyzer" method. Registered particles smaller than $0.02 \mu \mathrm{m}^{2}$ were excluded from the analysis to eliminate the influence of artifacts, which occurred due to image noise during thresholding of the image backgrounds. After all pictures were analyzed, the percentage of the green cells over the total was calculated and used to represent the membrane integrity. At least two replications and each have three technical replicates were made and all these fluorescent pictures were analyzed. The data were presented as means with standard deviations.

\section{Determination of ROS and Malondialdehyde (MDA)}

For the measurement of ROS, the cells were incubated with $10 \mu \mathrm{M} / \mathrm{L}$ dichlorodihydro-fluorescein diacetate (DCFH-DA) for $30 \mathrm{~min}$. Then, the cells were rinsed with $0.9 \% \mathrm{NaCl}(0.15 \mathrm{M})$ and seeded in black 96-well plates containing hematite particles. After incubating for 3 and 6 h, the green fluorescence (oxidized DCFH-DA), indicating the presence of oxidants, was measured using a fluorescence plate reader (PerkinElmer, Waltham, MA) at an excitation wavelength of $480 \mathrm{~nm}$ and an emission of $520 \mathrm{~nm}$. An additional experiment was performed to rule out that hematite and bacteria alone triggered ROS. Each experiment was performed independently in triplicate. 
The MDA concentration, as biological marker of oxidative stress was measured

after treating cells with hematite within $1 \mathrm{~h}$. The hematite and bacterial precipitates were collected by centrifugation at $10,000 \mathrm{~g}$ for $10 \mathrm{~min}$. Following the addition of 2 $\mathrm{mL} 10 \%$ trichloroacetic acid and $1 \mathrm{ml} 0.6 \%$ thiobarbituric acid, the suspensions were incubated for $30 \mathrm{~min}$ in boiling water. The supernatant was collected by centrifugation at $10,000 \mathrm{~g}$ for $10 \mathrm{~min}$ and the optical density (OD) was measured at wavelengths of 450, 532, and $600 \mathrm{~nm}$. The concentration of MDA $(\mu \mathrm{M} / \mathrm{mL})$ was calculated by the following formula: $\left[6.45 *\left(\mathrm{OD}_{532}-\mathrm{OD}_{600}\right)-0.56 * \mathrm{OD}_{450}\right] * 3{ }^{8}$

\section{Calculation for hydrophobicity.}

The hydrophobicity of the bacterium and minerals was evaluated in terms of the free energy of the interfacial interaction, $\Delta G_{\mathrm{iwi}}$, between two particles in water: ${ }^{3,9}$

$$
\Delta G_{\mathrm{iwi}}=-2\left(\sqrt{\gamma_{\mathrm{i}}^{\mathrm{LW}}}-\sqrt{\gamma_{\mathrm{w}}^{\mathrm{LW}}}\right)^{2}-4\left(\sqrt{\gamma_{\mathrm{i}}^{+}}-\sqrt{\gamma_{\mathrm{w}}^{+}}\right)\left(\sqrt{\gamma_{\mathrm{i}}^{-}}-\sqrt{\gamma_{\mathrm{w}}^{-}}\right)
$$

where $\gamma^{\mathrm{LW}}$ is the Lifshitz-van der Waals component of the surface tension $\left(\mathrm{mJ} / \mathrm{m}^{2}\right)$, and $\gamma^{+}$and $\gamma^{-}$are the electron-acceptor and electron-donor characteristics of the Lewis acid/base component of the surface tension $\left(\mathrm{mJ} / \mathrm{m}^{2}\right)$, respectively. The three unknown entities, $\gamma_{\mathrm{i}}^{\mathrm{LW}}, \gamma_{\mathrm{i}}^{+}$, and $\gamma_{\mathrm{i}}^{-}$in Equation (1) were determined using contact angle measurements with three different liquids (water, diiodomethane and formamide), and by solving Young's equation in the following form: ${ }^{9}$

$$
\gamma_{1}^{\mathrm{Tot}}\left(1+\cos \theta_{\mathrm{li}}\right)=2\left(\sqrt{\gamma_{1}^{\mathrm{LW}} \gamma_{\mathrm{i}}^{\mathrm{LW}}}+\sqrt{\gamma_{1}^{+} \gamma_{\mathrm{i}}^{-}}+\sqrt{\gamma_{1}^{-} \gamma_{\mathrm{i}}^{+}}\right)
$$

where $\theta_{\mathrm{li}}$ is the contact angle of liquid 1 on solid $\mathrm{i}$, and the $\gamma$ with subscript 1 are surface tension properties of the probe liquids.

\section{Interaction energy calculation by ExDLVO theory.}

The interaction energy between the cells and hematite was calculated using the extended-Derjaguin-Landau-Verwey-Overbeek (ExDLVO) theory. ${ }^{10}$ This theory describes bacterial adhesion to minerals as a balance between LW force, Lewis acid/base interaction $(\mathrm{AB})$ and electrostatic force $(\mathrm{EL})$ :

$$
G^{\mathrm{Tot}}(d)=G^{\mathrm{LW}}(d)+G^{\mathrm{AB}}(d)+G^{\mathrm{EL}}(d)
$$

where $G(d)$ is the interaction energy between bacterium and minerals at a certain distance $(d)$, and different superscripts stand for different types of forces. The model 
for sphere-plate was selected to evaluate the interaction energy between bacterium and hematite. The van der Waals attractive interaction energy was calculated using the following equation: $:^{11,12}$

$$
G^{\mathrm{LW}}(d)=-\frac{A_{\mathrm{lw} 2 \mathrm{a}}}{12 d}\left[1+\frac{14 d}{\lambda}\right]^{-1}
$$

where $d$ is separation distance; a is radius of bacteria; $\lambda$ is the characteristic wavelength (usually taken as $100 \mathrm{~nm}$ ) ${ }^{12,13} A_{1 \mathrm{w} 2}$ is the Hamaker constant for bacteria and hematite in water and was calculated by using the following equation: ${ }^{14}$

$$
A_{1 \mathrm{w} 2}=24 \pi d_{0}^{2}\left(\sqrt{\gamma_{1}^{\mathrm{LW}}}-\sqrt{\gamma_{\mathrm{w}}^{\mathrm{LW}}}\right)\left(\sqrt{\gamma_{2}^{\mathrm{LW}}}-\sqrt{\gamma_{\mathrm{w}}^{\mathrm{LW}}}\right)
$$

$\gamma_{\mathrm{i}}^{\mathrm{LW}}$ in Equation (5) were determined using contact angle measurements and Equation (2).

The electrostatic double layer interaction can be determined according to the following equation: ${ }^{3,15}$

$$
G^{\mathrm{EL}}(d)=\pi \varepsilon a\left[2 \zeta_{1} \zeta_{2} \ln \left(\frac{1+e^{-\kappa d}}{1-e^{-\kappa d}}\right)+\left(\zeta_{1}{ }^{2}+\zeta_{2}{ }^{2}\right) \ln \left(1-e^{-2 \kappa d}\right)\right]
$$

where $\varepsilon$ is the permittivity of water $\left(6.96 \times 10^{-10} /\left(\mathrm{m}^{*} \mathrm{~V}^{2}\right)\right)$; $\zeta$ is Zeta-potential; $\kappa$ is the double-layer thickness ${ }^{-1}\left(=0.328 \times 10^{10} \times \mathrm{I}^{0.5} / \mathrm{m}\right)$.

$$
G^{\mathrm{AB}}(d)=2 \pi a \lambda_{\mathrm{AB}} G_{d 0}^{\mathrm{AB}} \exp \left[\frac{d_{0}-d}{\lambda_{\mathrm{AB}}}\right]
$$

where $\lambda_{\mathrm{AB}}$ is the decay length of water, taken as $0.5 \mathrm{~nm} ;{ }^{10}$ The distance of closest approach, $d_{0}$, is taken as $0.157 \mathrm{~nm} .{ }^{16,17} G_{d 0}^{\mathrm{AB}}$ is the Lewis acid/base free energy $\left(\mathrm{J} / \mathrm{m}^{2}\right)$ for the bacterium-mineral interaction at a minimum separation distance $\left(d_{0}\right)$ and can be determined from the surface tension parameters: ${ }^{9}$

$$
\Delta G_{d 0}^{\mathrm{AB}}=2\left(\sqrt{\gamma_{1}^{+}}-\sqrt{\gamma_{2}^{+}}\right)\left(\sqrt{\gamma_{1}^{-}}-\sqrt{\gamma_{2}^{-}}\right)-2\left(\sqrt{\gamma_{1}^{+}}-\sqrt{\gamma_{\mathrm{w}}^{+}}\right)\left(\sqrt{\gamma_{1}^{-}}-\sqrt{\gamma_{\mathrm{w}}^{-}}\right)-2\left(\sqrt{\gamma_{2}^{+}}-\sqrt{\gamma_{\mathrm{w}}^{+}}\right)\left(\sqrt{\gamma_{2}^{-}}-\sqrt{\gamma_{\mathrm{w}}^{-}}\right)
$$

\section{ATR-FTIR Measurements}

The FTIR spectrometer is equipped with a one-reflection horizontal attenuated total reflectance (ATR) accessory with a ZnSe internal reflection element (IRE) crystal. The horizontal $45^{\circ} \mathrm{ZnSe}$ ATR crystal was coated with a hematite film by drying $1.2 \mathrm{~mL}$ of a finely dispersed $1 \mathrm{mg} / \mathrm{mL}$ suspension on the crystal surface. ${ }^{18}$ The 
coated crystal was sealed in a flow cell and placed on the ATR stage inside the IR spectrometer. In each experiment, the $0.15 \mathrm{M} \mathrm{NaCl}$ solution was initially flowed over the hematite film at a rate of $1 \mathrm{~mL} / \mathrm{min}$ to obtain a background spectrum. Bacterial adsorption was carried out by flowing bacterial suspensions $\left(\mathrm{OD}_{600 \mathrm{~nm}}=2.0\right)$ using the same conditions for $4 \mathrm{~h}$. Each spectrum was collected every $10 \mathrm{~min}$, as a single beam (resolution $4 \mathrm{~cm}^{-1}$ ) of 64 repeated scans. ${ }^{19}$ The background spectrum consists of a combination of the $\mathrm{ZnSe}$ crystal, hematite particles, and $\mathrm{NaCl}$ solution. All successive spectra were subtracted from this background spectrum. The bacterial spectra were obtained by taking scans of the suspensions on $\mathrm{ZnSe}$, from which the $\mathrm{ZnSe}$ and $\mathrm{H}_{2} \mathrm{O}$ absorbance were subtracted to isolate the contributions of the microbial cells.

After baseline correction for the IR spectra using OPUS 5.5 software, the absorbance at $\sim 1550 \mathrm{~cm}^{-1}$ from the amide II band was employed to depict the increase in bacterial adsorption with time. The variation in fractional surface coverage with time was expected to follow the pseudo first-order kinetics equation:

$$
A=A_{\max }\left(1-\mathrm{e}^{-k t}\right)
$$

where $A$ is the absorbance of adhered bacteria to hematite, $A_{\max }$ is the absorbance at saturation coverage of bacteria and corresponds closely to a complete single layer of cells, $k$ is the adsorption rate constant, and $t$ is the adsorption time. ${ }^{20}$

The two-dimensional correlation analysis (2D-COS) is performed to describe a correlation contour map by a correlation analysis to time stimulated spectral fluctuation. The 2D-COS was performed on FTIR spectra from 1750 to $900 \mathrm{~cm}^{-1}$ using 2D Shige software (Shigeaki Morita, Japan). To distinguish the initial adhesion and the long-term interfacial reaction processes, the spectra from 0 to $2 \mathrm{~h}$ and $4 \mathrm{~h}$ were chosen for 2D correlation analysis, respectively. The peak assignments are: 1644 $\mathrm{cm}^{-1}$ amide I; $1547 \mathrm{~cm}^{-1}$ amide II; $1454 \mathrm{~cm}^{-1} \gamma \mathrm{CH}_{2} / \mathrm{CH}_{3} ; 1399 \mathrm{~cm}^{-1} v_{\mathrm{s}}\left(\mathrm{COO}^{-}\right)$; $\sim 1240-1220 \mathrm{~cm}^{-1} v_{\text {as }}\left(\mathrm{PO}_{2}\right) ; \sim 1090 \mathrm{~cm}^{-1} v_{\mathrm{s}}\left(\mathrm{PO}_{2}\right) / \mathrm{C}-\mathrm{C}$ vibrations of polysaccharides; $1047 \mathrm{~cm}^{-1} v(\mathrm{P}-\mathrm{OFe})$ and $990 \mathrm{~cm}^{-1} v_{a s}\left(\mathrm{P}-(\mathrm{OFe})_{2}\right.$.

The intensity of a synchronous correlation spectrum $\Phi\left(v_{1}, v_{2}\right)$ represents the simultaneous or coincidental changes of two separate spectral intensity variations measured at $v_{1}$ and $v_{2}$ during the interval between $T_{\min }$ and $T_{\max }$ of the externally 
defined variable time. The intensity of an asynchronous spectrum $\psi\left(v_{1}, v_{2}\right)$ represents sequential or successive, but not coincidental, changes of spectral intensities measured separately at $v_{1}$ and $v_{2}$. The rank order of intensity change between two bands at $v_{1}$ and $v_{2}$ can be obtained from the signs of the synchronous correlation peak $\Phi\left(v_{1}, v_{2}\right)$ and asynchronous correlation peak $\psi\left(v_{1}, v_{2}\right)$ based on previously established principles. ${ }^{21,22}$ Briefly, for a synchronous cross peak, the sign becomes positive if the spectral intensities at the two bands at $v_{1}$ and $v_{2}$ corresponding to the coordinates of the cross peak are either increasing or decreasing together as functions of the external variable time during the observation interval, otherwise, the sign becomes negative; while for an asynchronous cross peak, the sign becomes positive if the intensity change at $v_{1}$ occurs predominantly before that at $v_{2}$ in the sequential order of time, otherwise, the sign becomes negative. If $\Phi\left(v_{1}, v_{2}\right)$ and $\psi\left(v_{1}, v_{2}\right)$ have the same signs, the changes in the spectral intensity at band $v_{1}$ will occur prior to those at $v_{2}$; if they have opposite signs, the order will be reversed. If $\psi\left(v_{1}, v_{2}\right)$ is zero, then the changes at $v_{1}$ and $v_{2}$ will occur simultaneously.

\section{Near Edge X-ray Absorption Fine Structure Spectroscopy}

The ratios of $\mathrm{Fe}^{3+} / \mathrm{Fe}^{2+}$ on hematite and the chemical species of $\mathrm{C}, \mathrm{N}$ and $\mathrm{S}$ were determined using XANES to assess the oxidative damage to bacteria. Each of the hematite-bacteria mixture was analyzed at the 4B7A and 4B7B beamlines of Beijing Synchrotron Radiation Facility. The electron storage ring is $2.5 \mathrm{GeV}$ with a $\mathrm{Si}$ (111) double crystal. Homogenized powder was spread as thin film on conductive tapes for analysis. Spectra were recorded at the energy region between 270 and $310 \mathrm{eV}$ for $\mathrm{C}-\mathrm{K}$ edge; 390 and $420 \mathrm{eV}$ for N-K edge; 2450 and $2520 \mathrm{eV}$ for S-K edge; 680 and $750 \mathrm{eV}$ for $\mathrm{Fe}-\mathrm{L}_{2} / \mathrm{L}_{3}$ edge. The contribution of each species for $\mathrm{C}, \mathrm{N}$ and $\mathrm{S}$ was calculated using Gaussian and arctangent functions (GCF) which is implemented in the software package Athena. For C-XANES data, the deconvolution parameters were referred from previous studies. ${ }^{23-25}$ The center position, amplitude and width of the arctangent function were fixed to $291.5 \mathrm{eV}, 1.0$ and $0.4 \mathrm{eV}$, respectively. Each Gaussian function had a fixed energy position and a constant width of $0.4 \mathrm{eV}$. The peak at 285.6, 287.6, 288.3, 288.7, 289.6 and $290.5 \mathrm{eV}$ referred to as aromatic, alkyl, amide/carboxyl, 
263

264

265

266

267

268

269

270

271

272

273

274

275

276

277

278

279

carboxyl/ester/acetal, O-alkyl and carbonyl C, respectively. ${ }^{23,26,27}$ The N-XANES spectra showed features at $399.4 \mathrm{eV}$ (aromatic $\mathrm{N}$ in rings), $401.0 \mathrm{eV}$ (amide), 402.6 $\mathrm{eV}$ (pyrrolic), $404.0 \mathrm{eV}$ (N-bonded aromatic) and $405.5 \mathrm{eV}$ (inorganic $\mathrm{NO}_{3}{ }^{-}$). ${ }^{28}$ Each Gaussian function was fixed to these energy positions and constant width of 0.4 to 1 $\mathrm{eV}$. The center position, the amplitude and the width of the arctangent function are fixed to $404 \mathrm{eV}, 1.0$ and $0.4 \mathrm{eV}$, respectively. For $\mathrm{S}$ spectra, two arctangent functions were selected representing the specific edge step. ${ }^{29}$ Their center position, amplitude and width were fixed to $2475.7 \mathrm{eV}, 1$ and $0.66 \mathrm{eV} ; 2482.5 \mathrm{eV}, 0.12$ and $0.66 \mathrm{eV}$, respectively. Five Gaussian functions were taken into account for the K-edge S-XANES ranging from 2466 to $2487 \mathrm{eV}$. Their white line position and electronic oxidation state (OS) are: $2473.5 \mathrm{eV}(\mathrm{OS}=0.5), 2474.40 \mathrm{eV}(\mathrm{OS}=1), 2476.40 \mathrm{eV}$ $(\mathrm{OS}=2), 2479.00 \mathrm{eV}(\mathrm{OS}=4)$ and $2481.00 \mathrm{eV}(\mathrm{OS}=5)$, respectively. The full width at half maximum of each Gaussian component for low-valent $S(<2)$ is constrained at $0.6 \mathrm{eV}$, while that for higher valent $\mathrm{S}$ are constrained at $1.4 \mathrm{eV}$. The areas of different Gaussian peaks were calculated and corrected for their OS-dependent absorption cross section by a generic curve. ${ }^{29}$ 


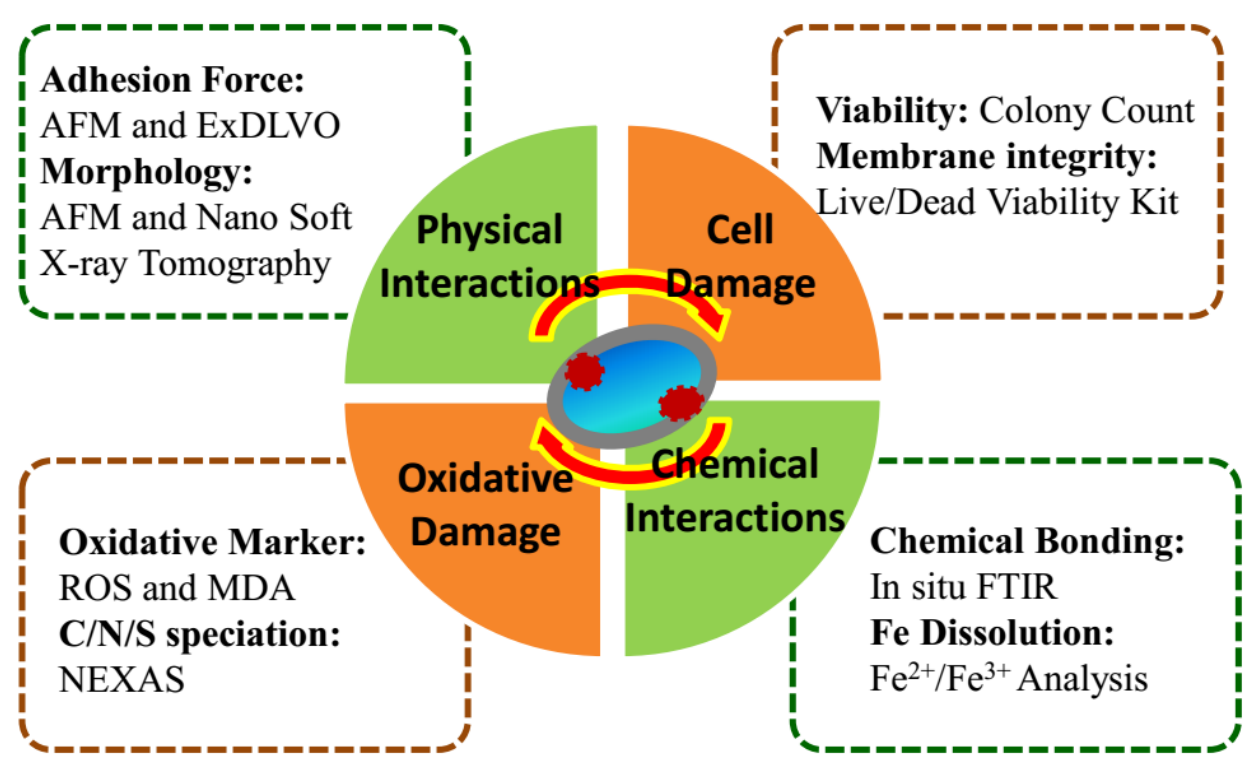

282 Supplementary Figure 1: Overview of the experimental set-up, green fields indicate

283 the analytical techniques for physical and chemical interactions and brown fields

284 show the cellular responses in the presence of hematite particles. 

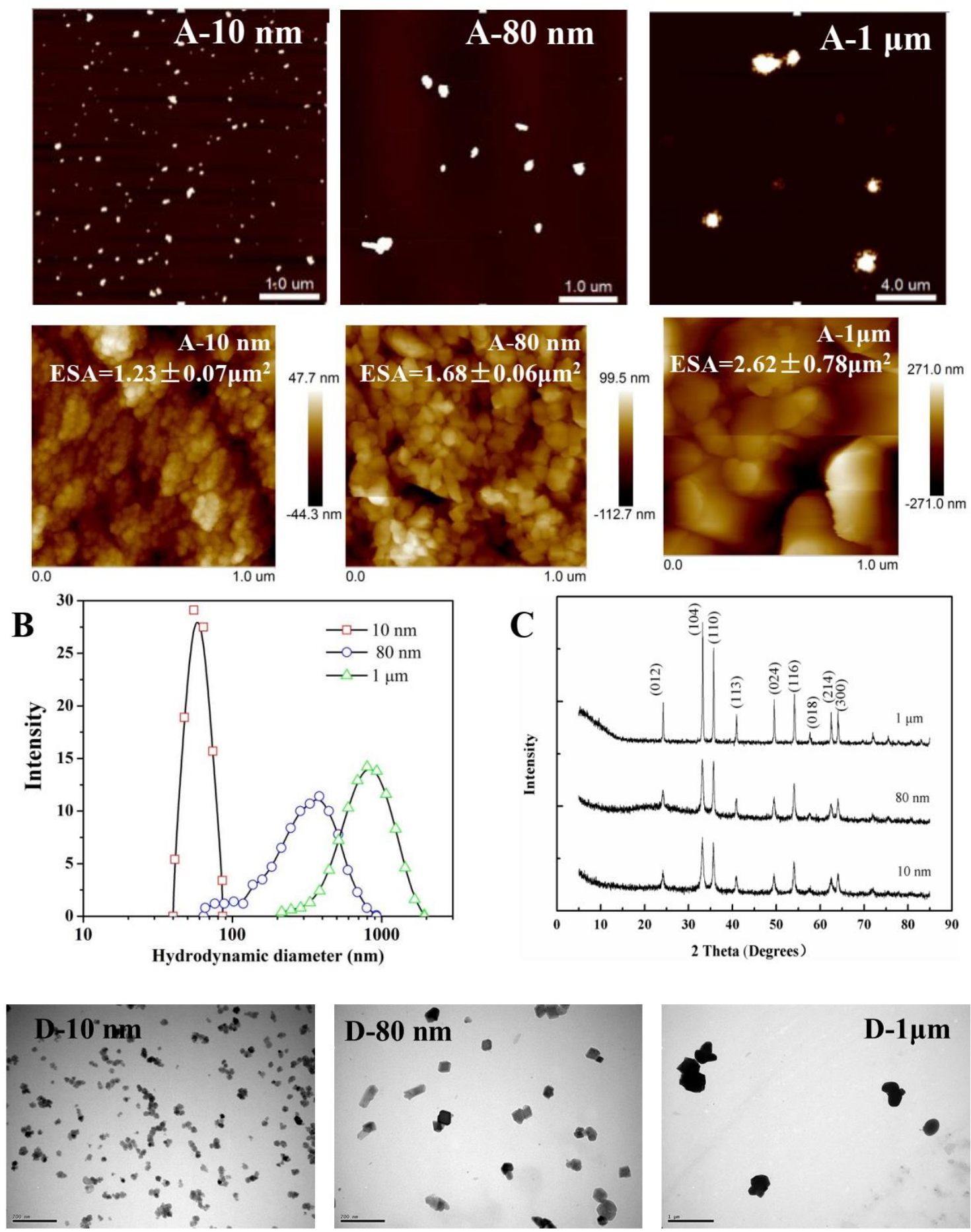

Supplementary Figure 2. Characterization of hematite particles as shown by

AFM height images (A), hydrodynamic size distributions in pH $5 \mathrm{HNO}_{3}(\mathrm{~B}), \mathrm{XRD}$

patterns (C) and TEM images (D). The ESA represents the exposed surface area in the scanned 1 square micrometer. The scale bar in TEM images is $200 \mathrm{~nm}$ for $10 \mathrm{~nm}$ and $80 \mathrm{~nm}$ hematite, and $1 \mu \mathrm{m}$ for $1 \mu \mathrm{m}$ hematite. 

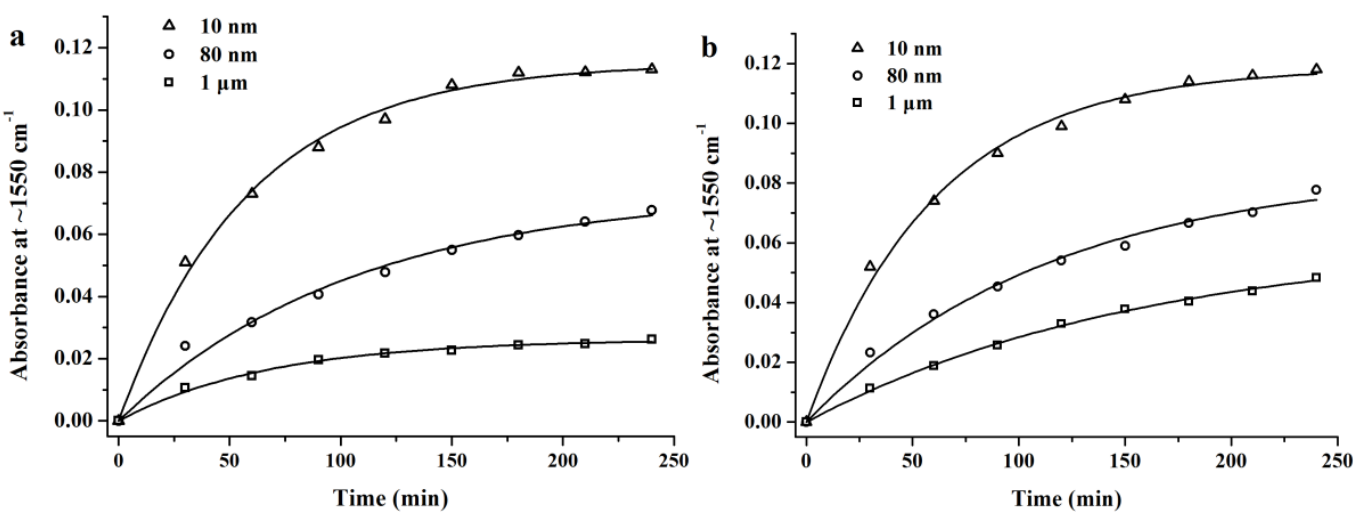

293

294

295

296

297

298

299

300

301
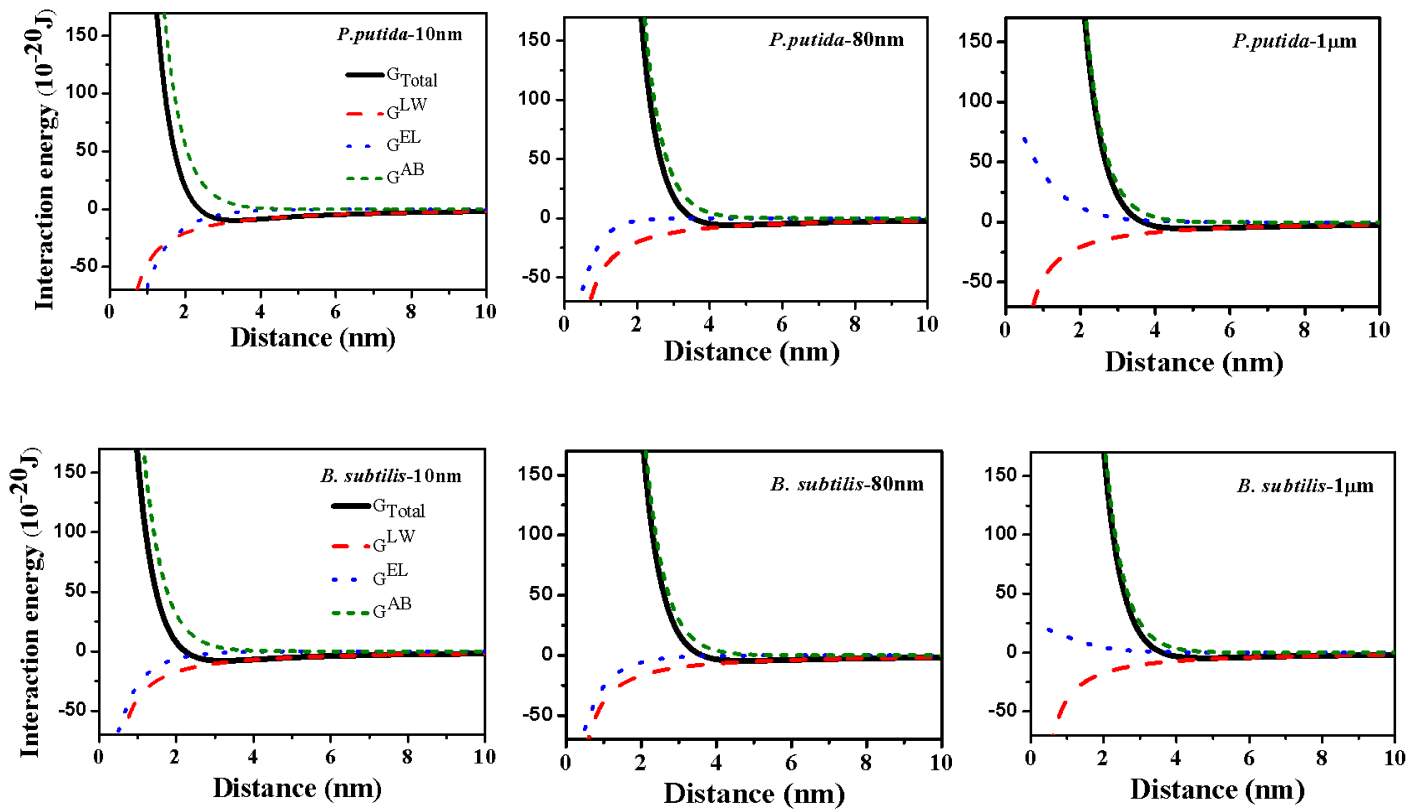

Supplementary Figure 4. Profiles for the ExDLVO simulations of the Lifshitz-van der Waals (LW) force, Lewis acid/base interaction $(\mathrm{AB})$ and electrostatic force (EL), and total interaction energy between bacteria and hematite particles. 


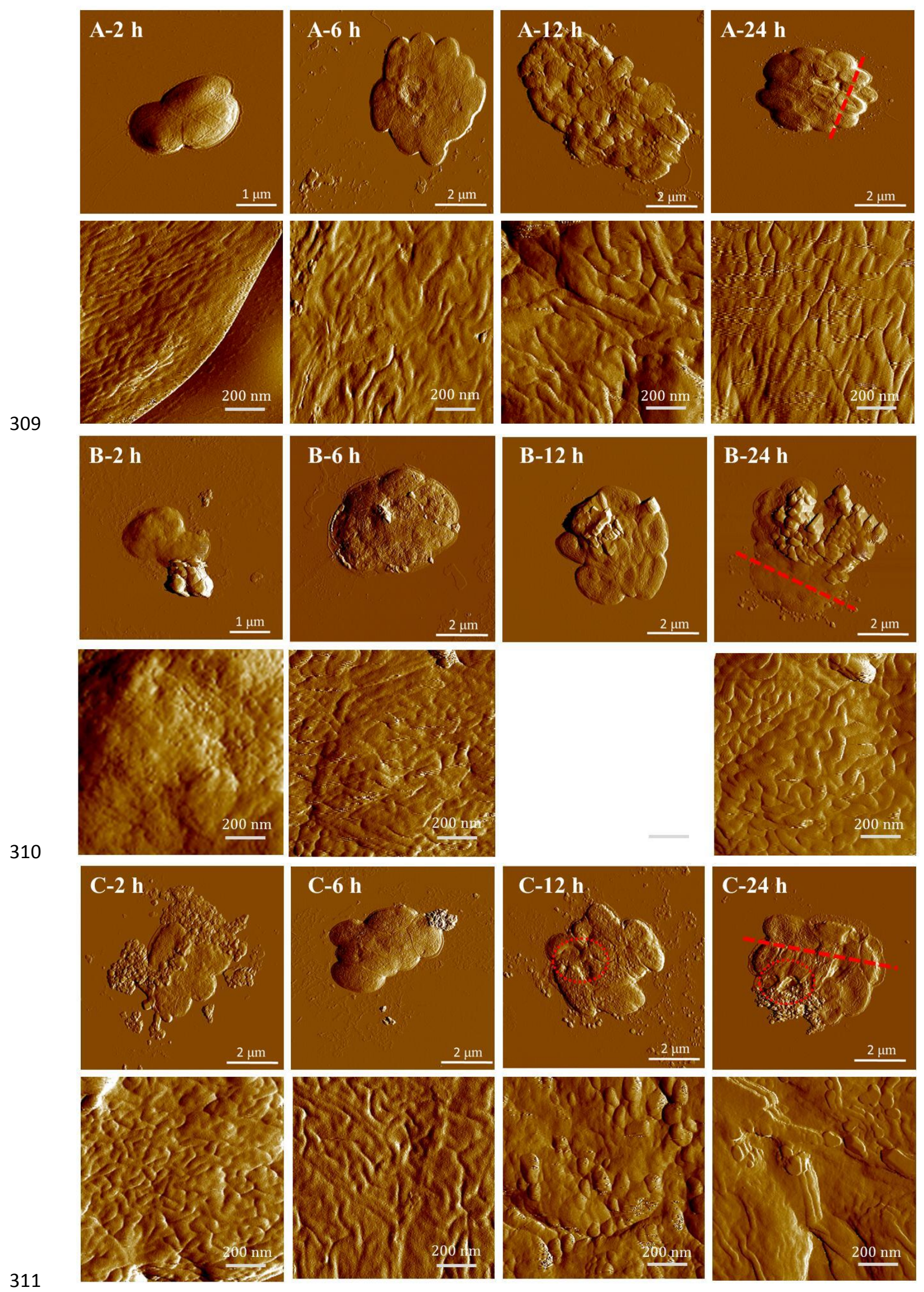



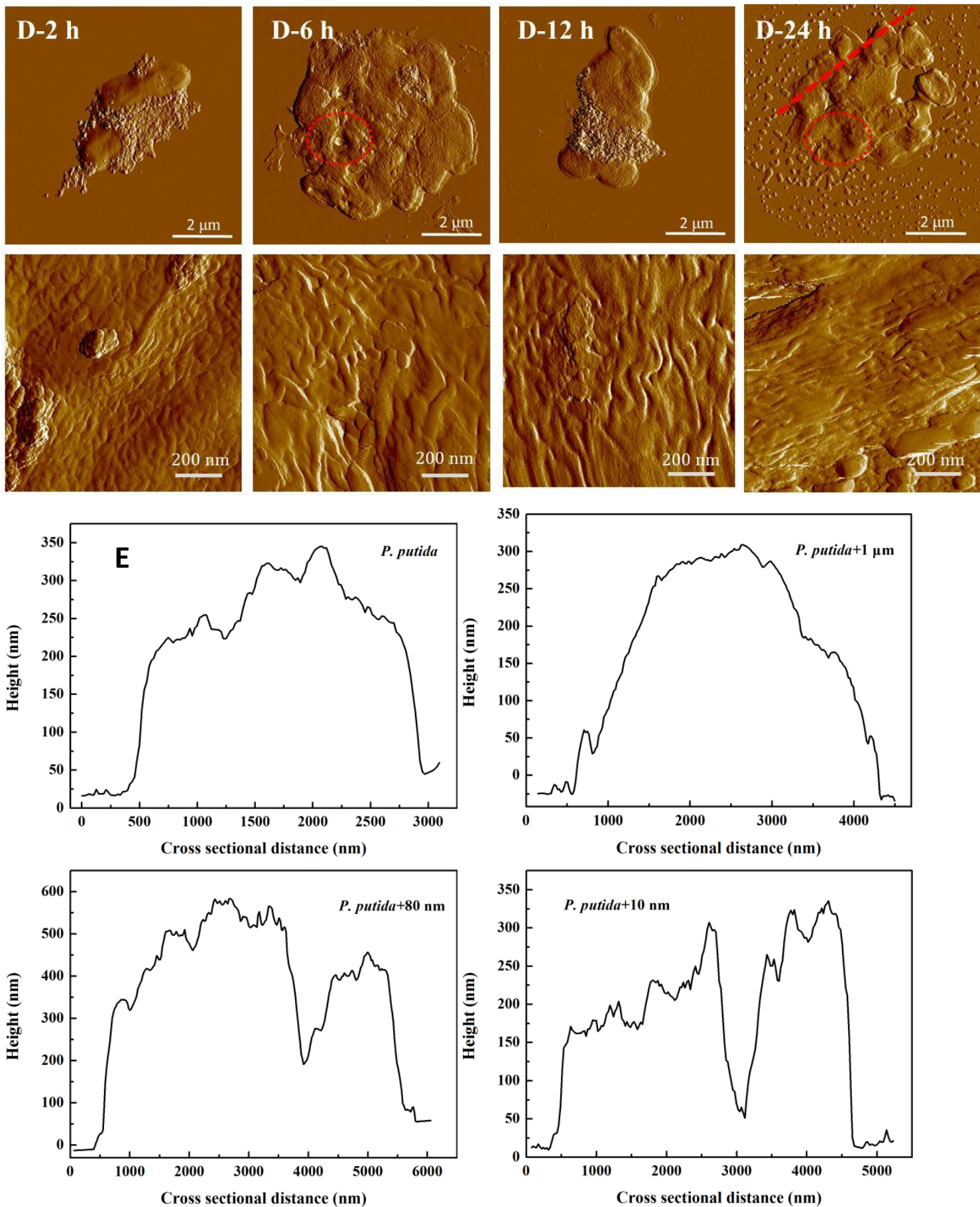

Supplementary Figure 5. AFM images of $P$. putida cells in the absence (A) and presence of $1 \mu \mathrm{m}(\mathrm{B}), 80 \mathrm{~nm}(\mathrm{C})$ and $10 \mathrm{~nm}$ (D) hematite particles at different time scales. Their regional amplificatory images are listed below to emphasize the changes on bacterial surfaces. The cross-sectional profiles (E) of the cells after $24 \mathrm{~h}$ incubation with hematite are taken along the red dashed lines in panels A to D, respectively. 

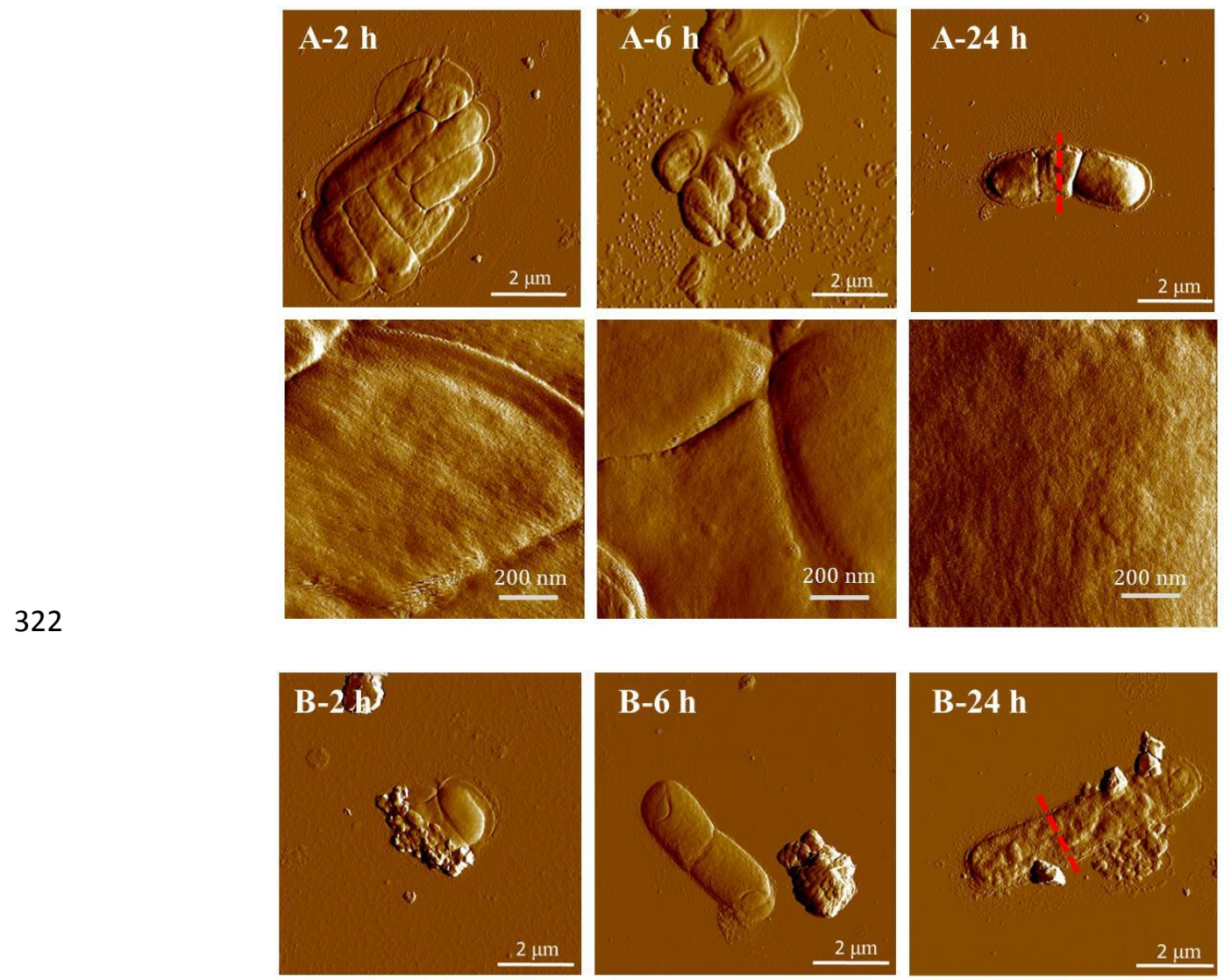

\section{B-24 h}


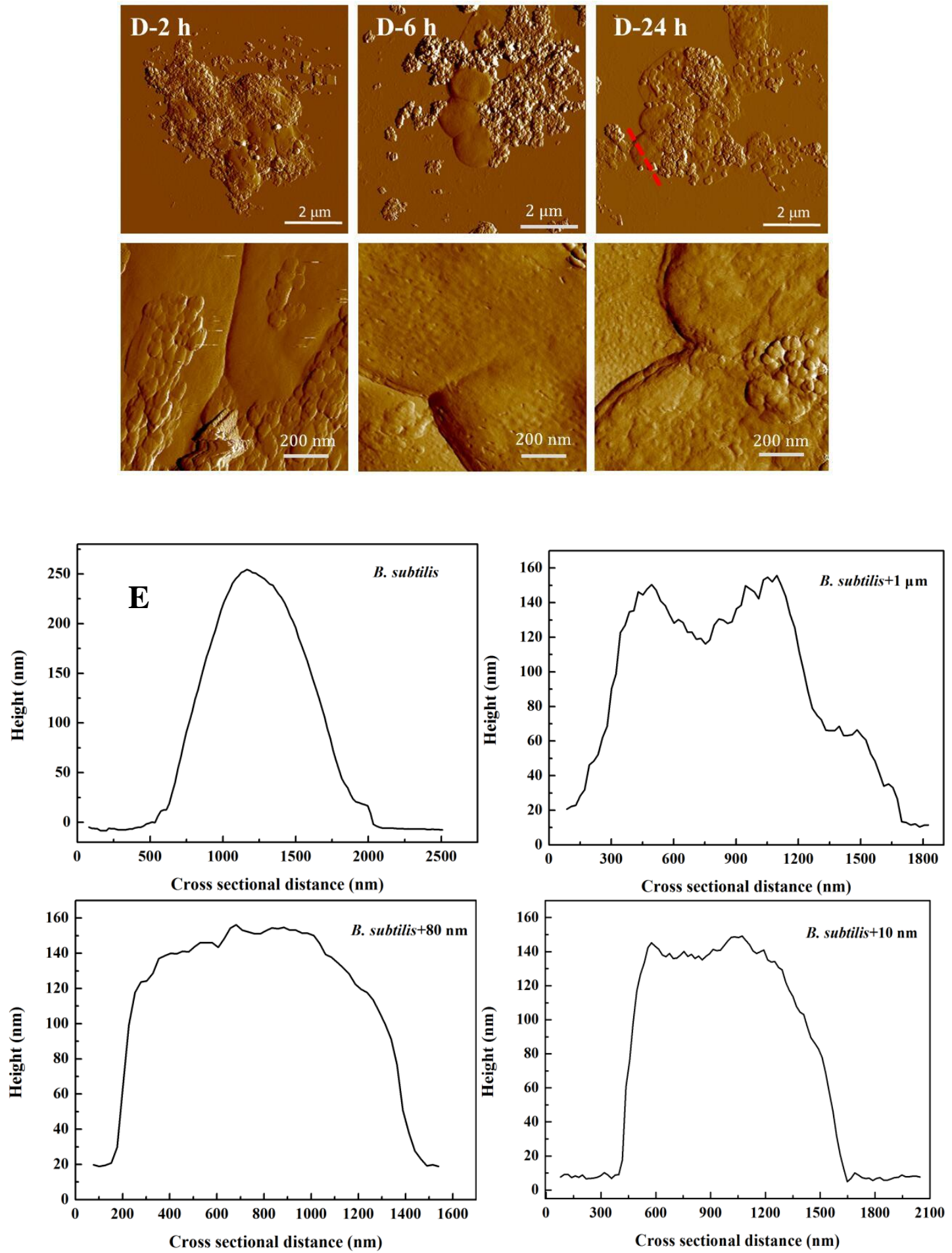

Supplementary Figure 6. AFM images of $B$. subtilis cells in the absence (A) and presence of $1 \mu \mathrm{m}(\mathrm{B}), 80 \mathrm{~nm}(\mathrm{C})$ and $10 \mathrm{~nm}(\mathrm{D})$ hematite particles at different time scales. Their regional amplificatory images are listed below to emphasize the changes

332 on bacterial surfaces. The cross-sectional profiles (E) of the cells after $24 \mathrm{~h}$ incubation 333 with hematite are taken along the red dashed lines in panels A to D, respectively. 

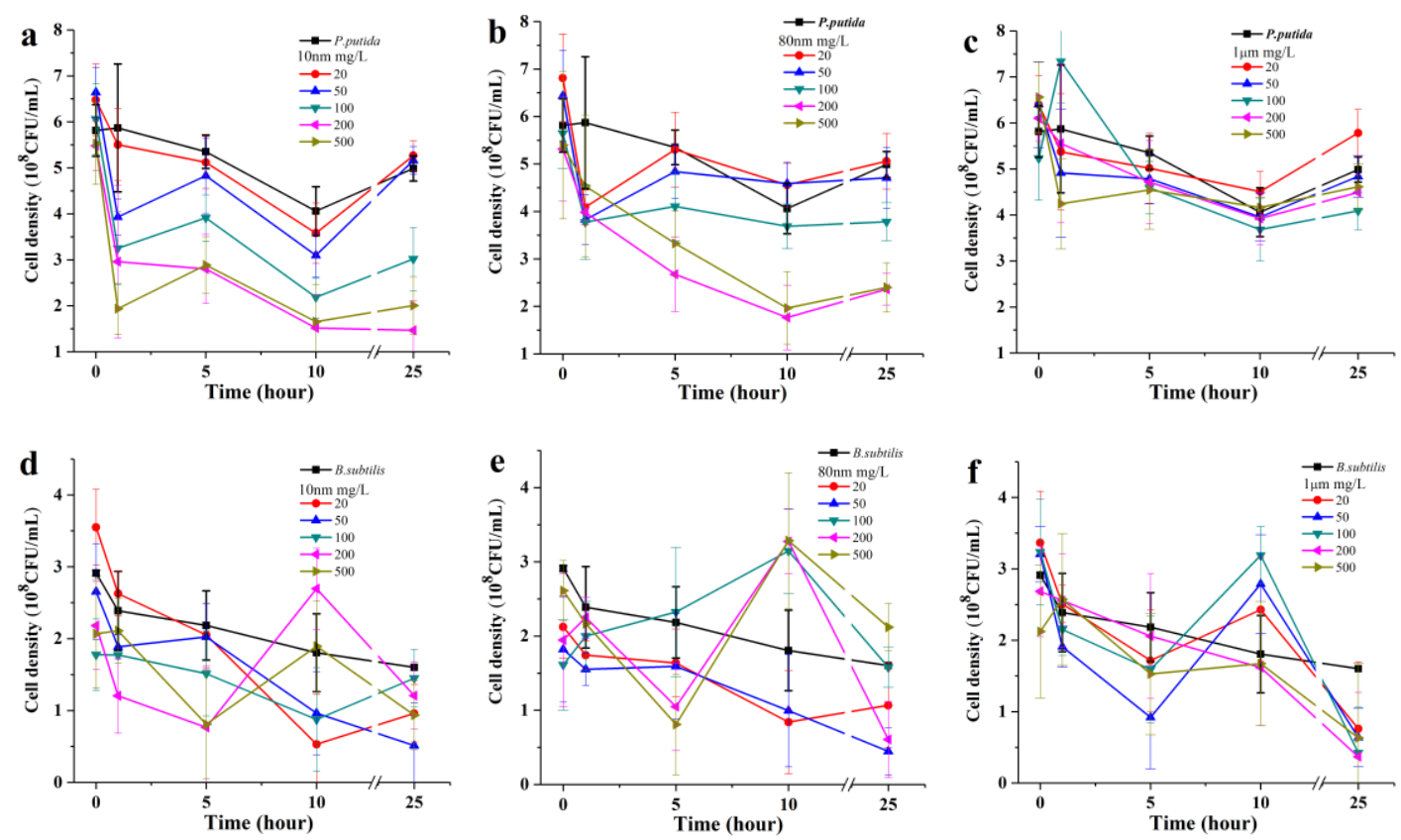

Supplementary Figure 7. The cellular viability of $P$. putida (a-c) and B. subtilis (d-f) based on spread plate method for different hematite size, concentration and contact time. Data are shown as mean \pm standard deviation. 


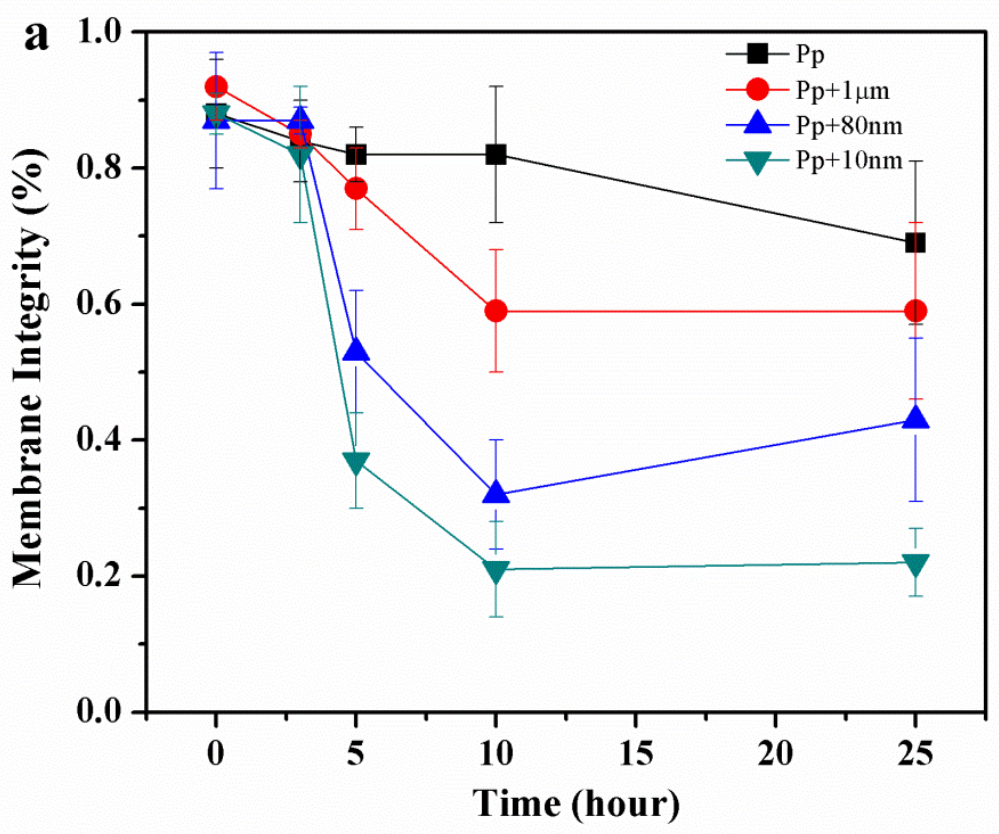

352

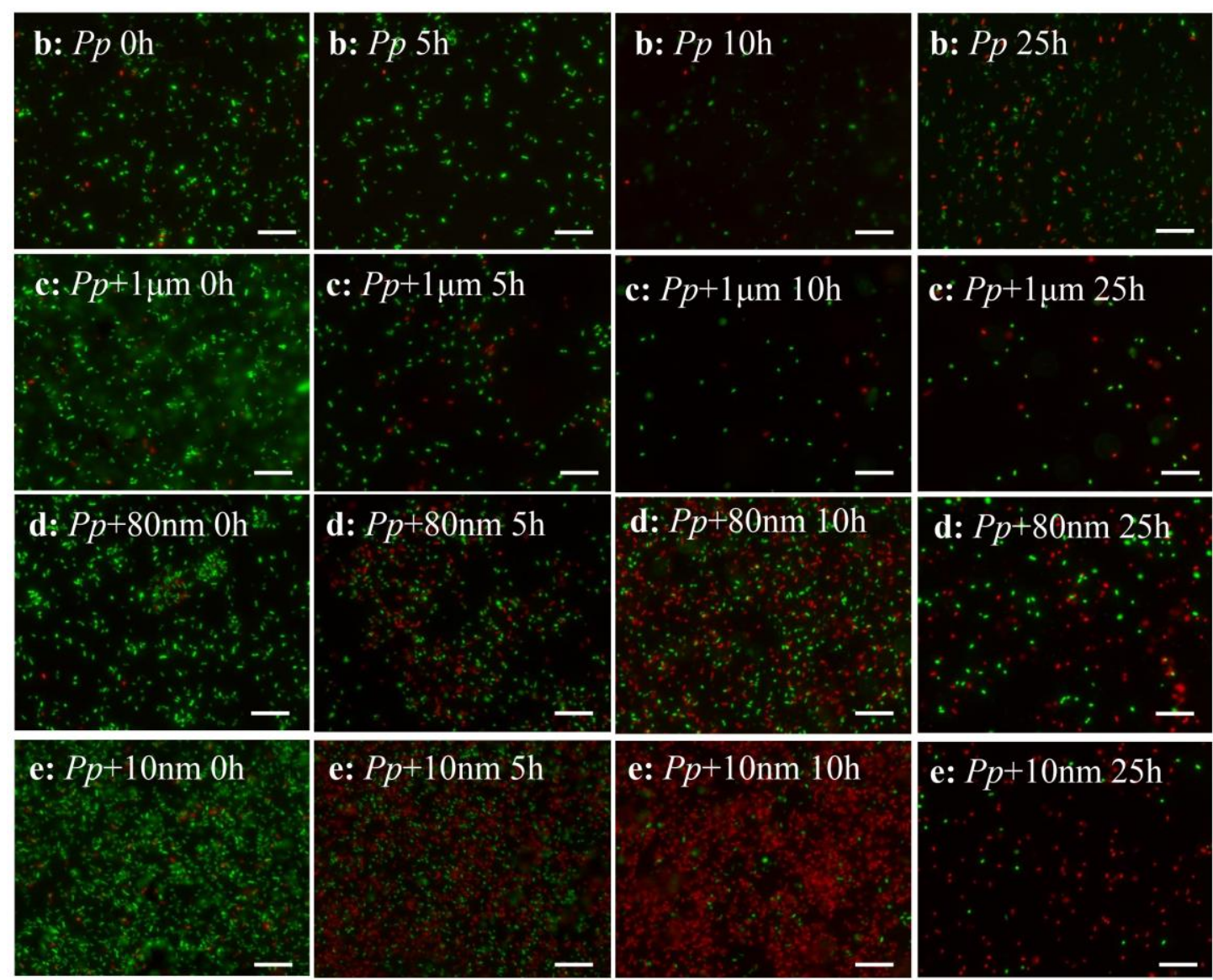



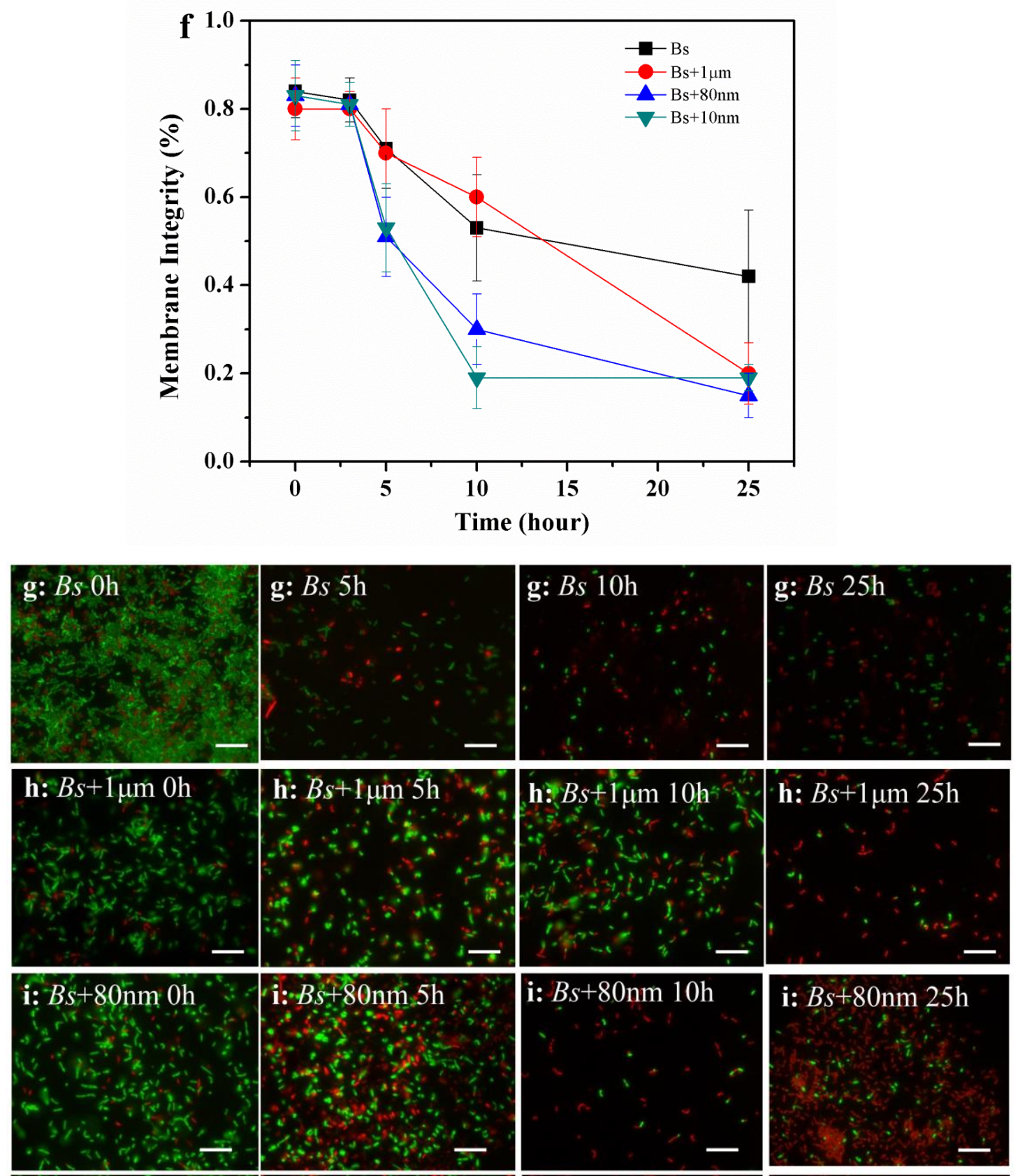

$\mathbf{h}: B s+1 \mu \mathrm{m} 25 \mathrm{~h}$
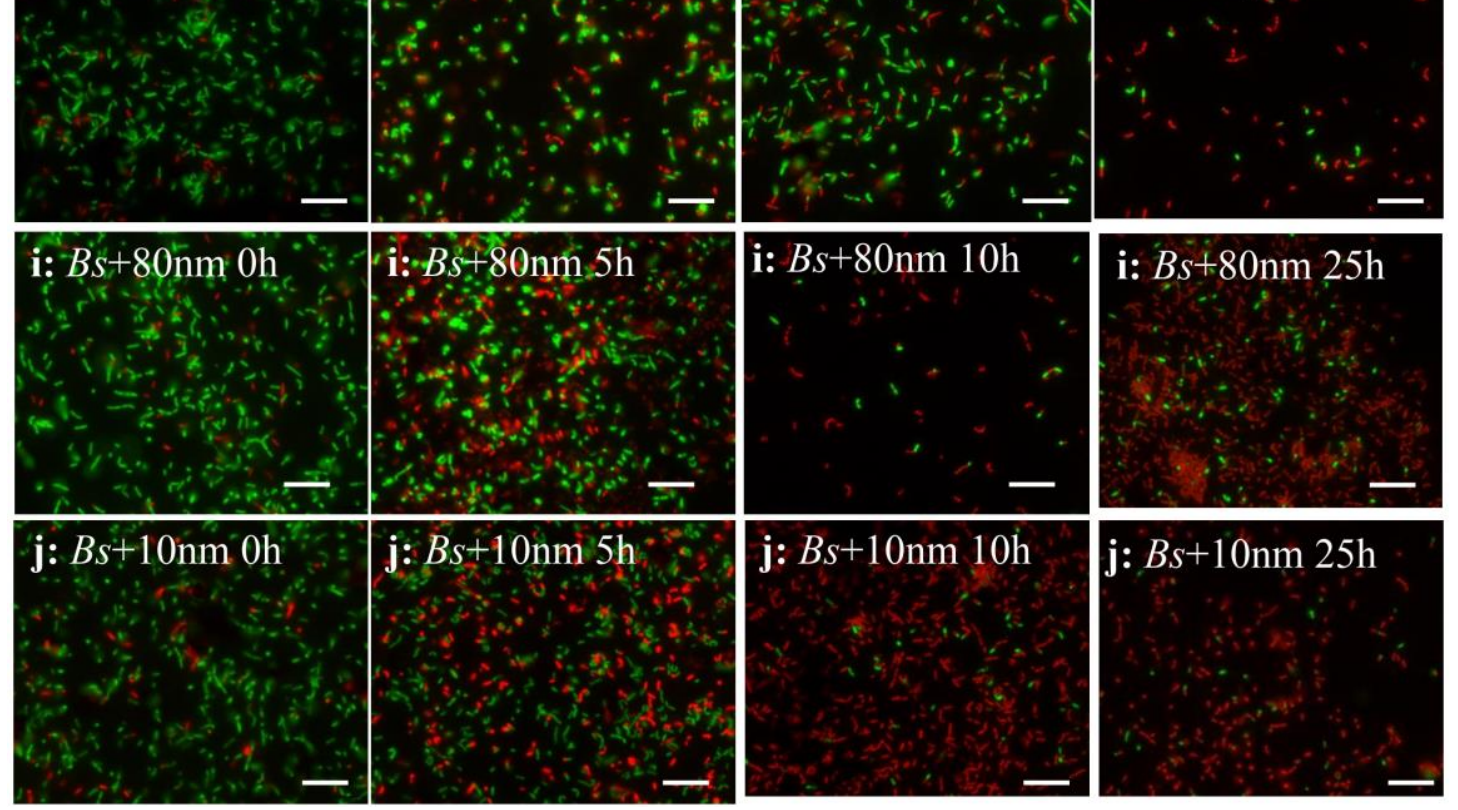

Supplementary Figure 8. Membrane integrity of $P$. putida (a) and B. subtilis cells (f), and representative epifluorescence pictures of intact (green) and broken (red) cells.

358 Data were obtained for bacteria after $0,3,5,10,25 \mathrm{~h}$ contact with hematite in $0.9 \%$ $359 \mathrm{NaCl}$. b-e are images for P. putida in the absence and presence of $1 \mu \mathrm{m}, 80 \mathrm{~nm}$ and 10 $360 \mathrm{~nm}$ hematite, respectively. g-j are images for $B$. subtilis in the absence and presence of $3611 \mu \mathrm{m}, 80 \mathrm{~nm}$ and $10 \mathrm{~nm}$ hematite, respectively. 

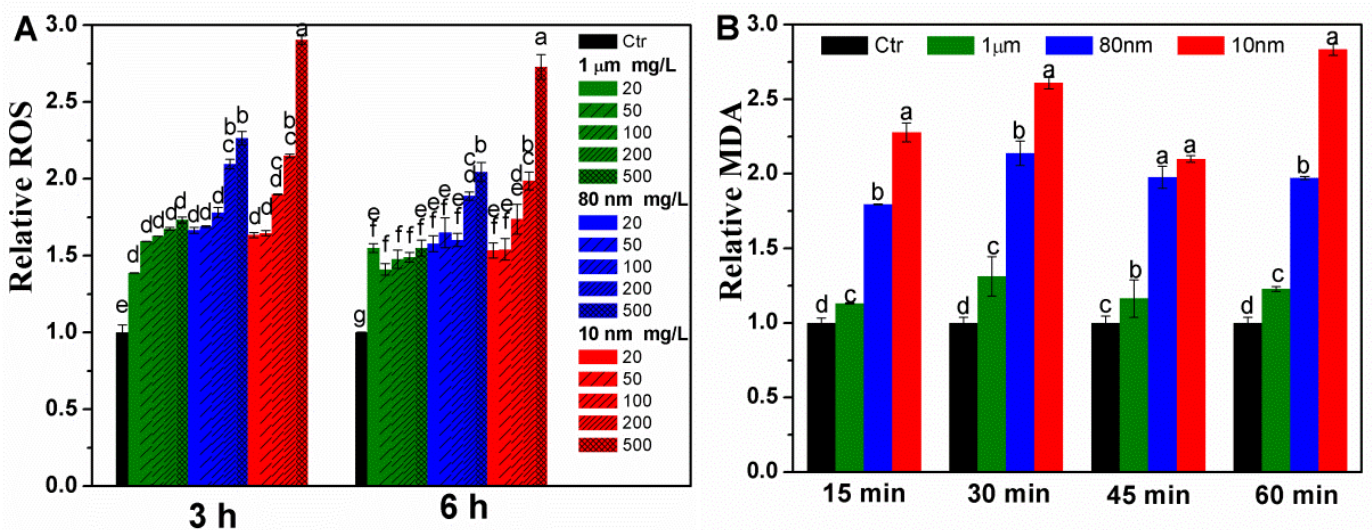

363
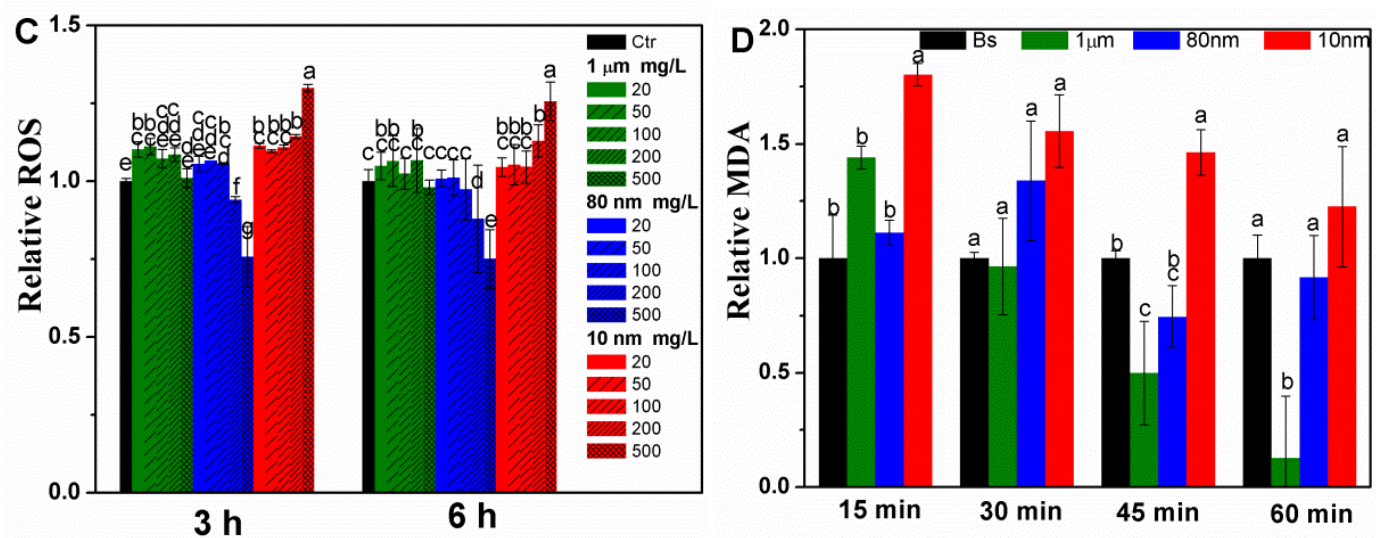

364

Supplementary Figure 9. The relative rates of ROS and MDA for bacteria-hematite

systems as influenced by different size, concentration and contact time of hematite particles. A and B are ROS and MDA for P. putida, while C and D are ROS and MDA for B. subtilis, respectively. For each assay, values labeled with the same letter are not significantly different (analysis of variance, $\mathrm{P}<0.05$ ). 

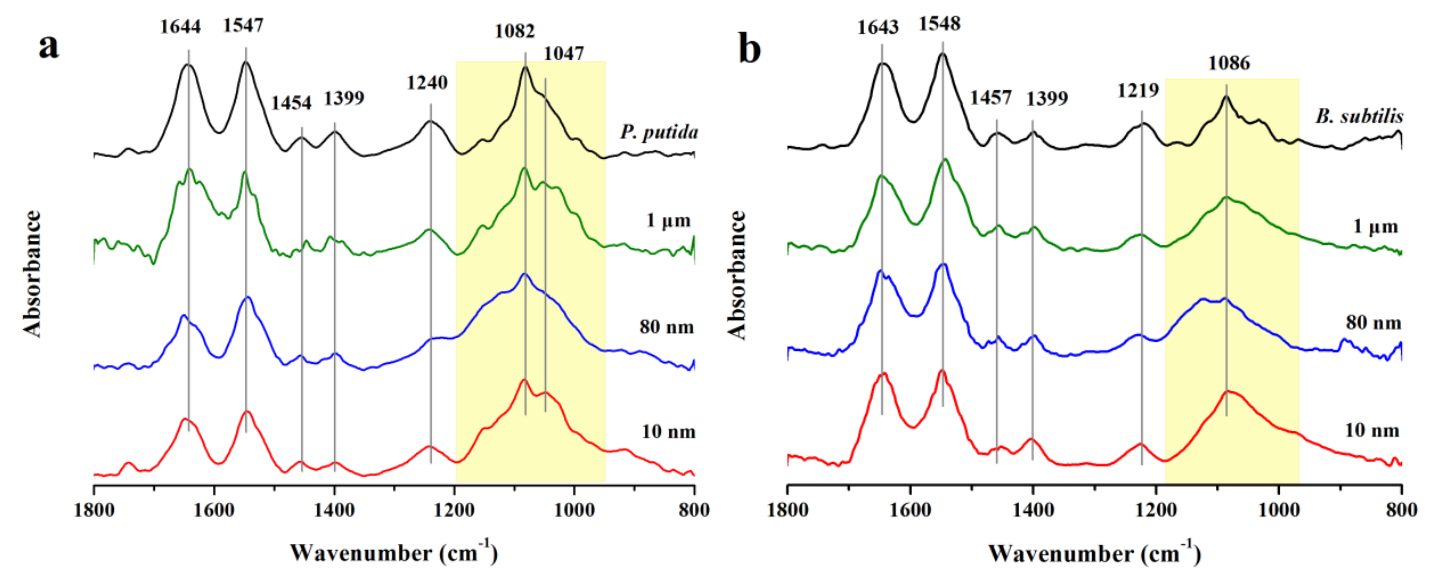

373 Supplementary Figure 10. ATR-FTIR spectra of $P$. putida (a) and B. subtilis (b) 374 recorded on $\mathrm{ZnSe}$ and hematite film surface in $0.9 \% \mathrm{NaCl}$.
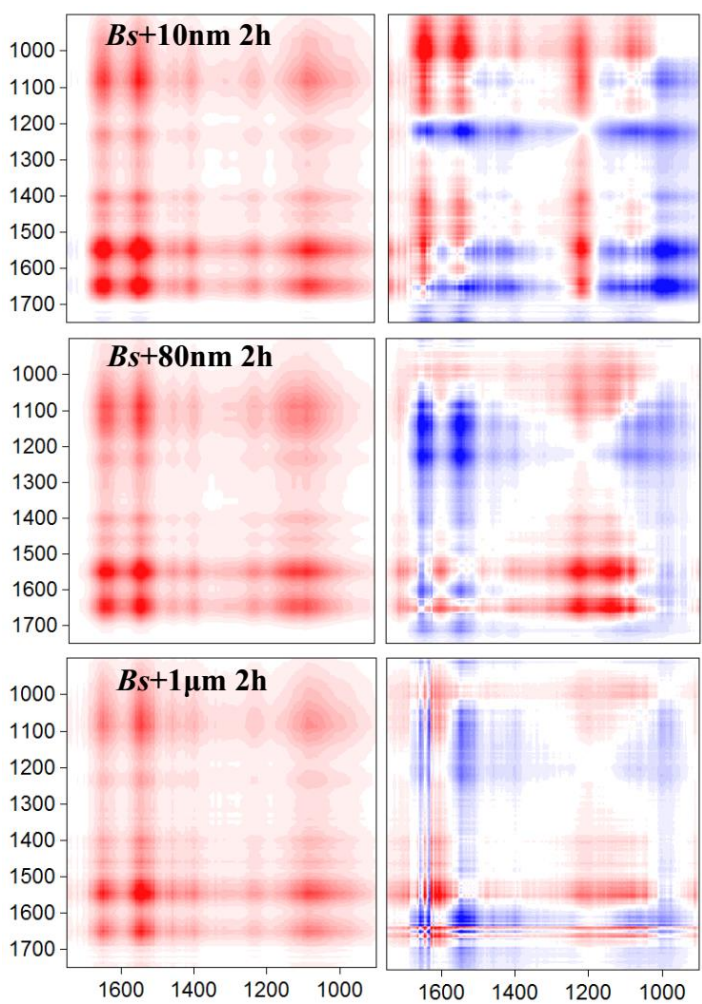
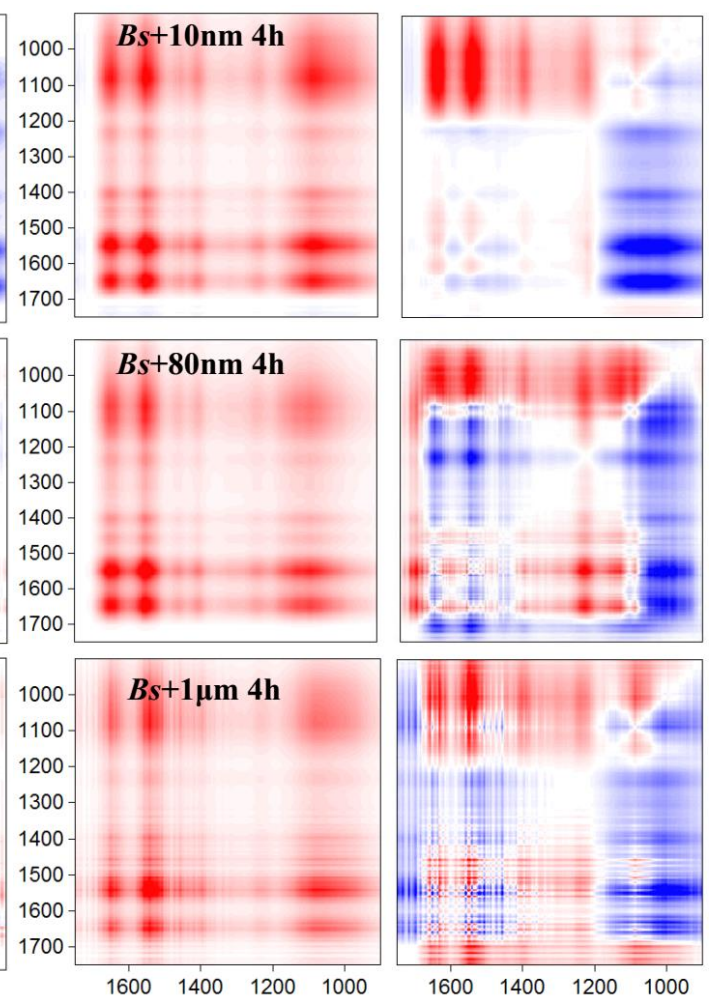

Supplementary Figure 11. The synchronous (left) and asynchronous (right) 2D correlation contour maps of time-dependent ATR-FTIR spectra for B. subtilis cells adhered on deposited hematite film for 2 and $4 \mathrm{~h}$. The red and blue regions represent positive and negative correlations, respectively. 



384


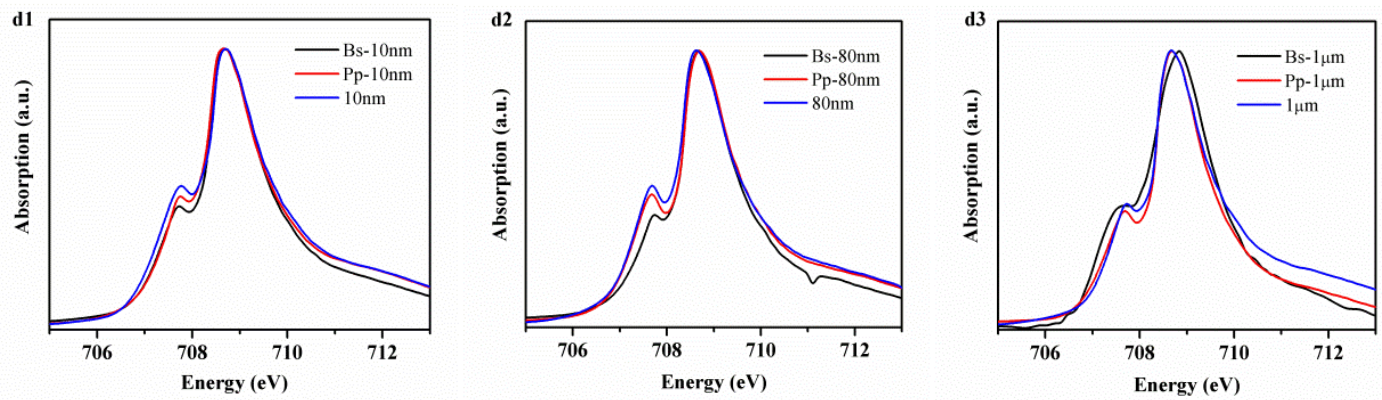

Supplementary Figure 12. The XANES spectra of carbon (a), nitrogen (b), sulfur (c) and iron (d) for bacteria, hematite and their complexes.

Intracellular Accumulation is Key Step for Particle Bacterial Toxicity


\section{Target on Phospholipid and Protein}

Supplementary Figure 13. Schematic diagram for the size-dependent interaction mechanism between hematite particles and bacteria. The bacterial toxicity of hematite particles start from their adhesion onto bacterial cells. The mineral particles could from $\mathrm{P}-\mathrm{O}-\mathrm{Fe}$ bonds on bacterial surfaces, while nano hematite particles change the protein structure on bacterial surface, resulting in the loss of membrane integrity and migration into the cells. Once contact, reactive oxygen species are generated at the surface of hematite particle, inducing oxidative damage such as cell lipid peroxidation. $\mathrm{G}^{+}$bacteria exhibit weaker adhesion forces toward hematite and benefit from the protection of the peptidoglycan layers, showing higher resistance against hematite toxicity. 

bacteria and three hematites.

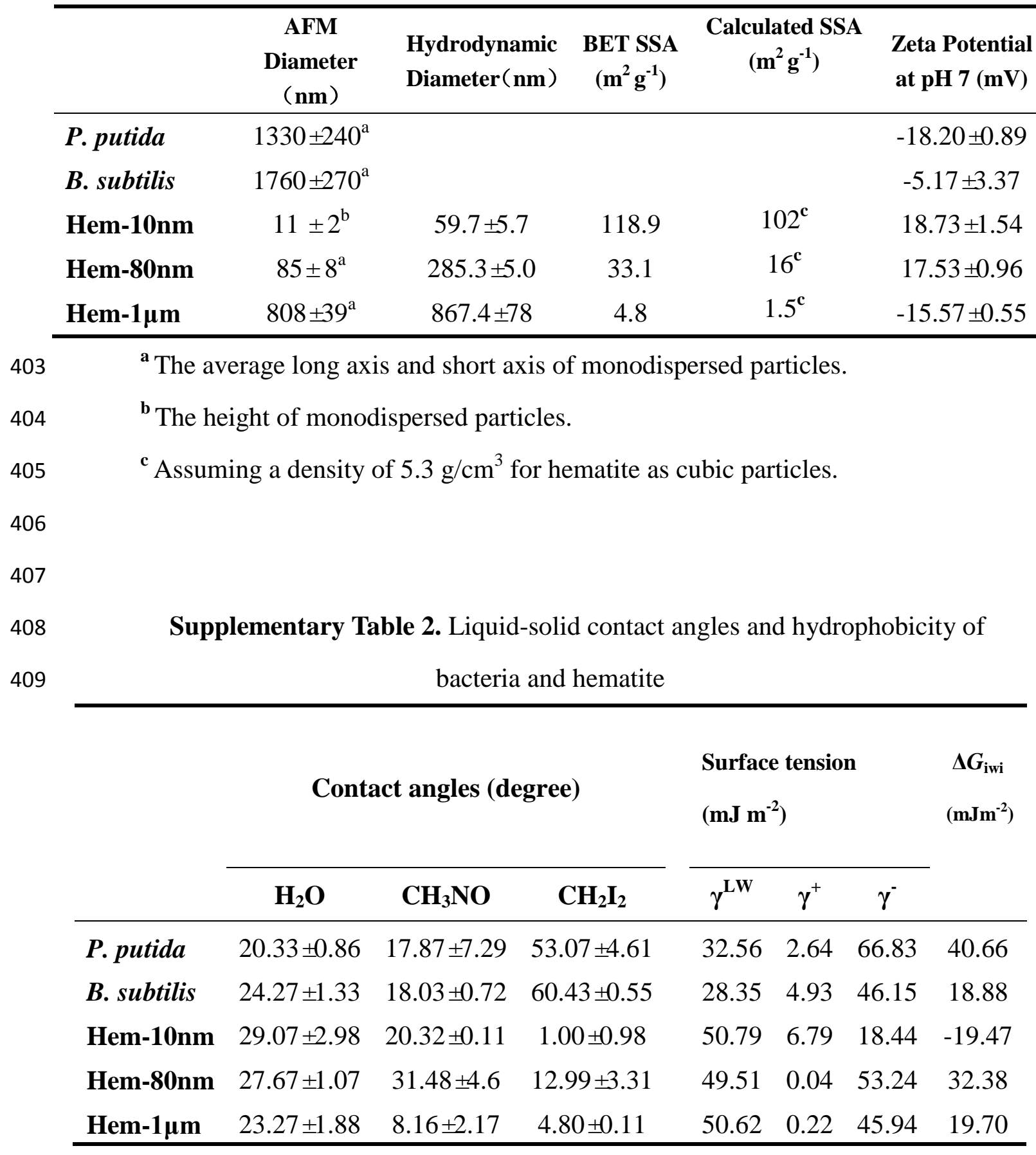


416 Supplementary Table 3. Concentrations of $\mathrm{Fe}^{2+}$ ions and total concenrations of $\mathrm{Fe}$ ions for hematite in the presence of P. putida and B. subtilis

\begin{tabular}{|c|c|c|c|c|c|c|c|}
\hline & $\begin{array}{c}\text { Ferrozine } \\
\text { soluble } \mathrm{Fe}^{2+} \\
(\mu \mathrm{mol} / \mathrm{g})\end{array}$ & & $\begin{array}{c}\text { Oxalate-EDTA } \\
\text { soluble } \mathrm{Fe}^{2+/ 3+} \\
(\mu \mathrm{mol} / \mathrm{g})\end{array}$ & & $\begin{array}{c}\text { Oxalate-EDTA } \\
\text { soluble } \mathrm{Fe}^{2+/ 3+} \\
\quad(\mu \mathrm{mol} / \mathrm{g})\end{array}$ & & $\begin{array}{c}\text { Oxalate-EDTA } \\
\text { soluble } \mathrm{Fe}^{2+/ 3+} \\
(\mu \mathrm{mol} / \mathrm{g})\end{array}$ \\
\hline $10 \mathrm{~nm}$ & $35.1 \pm 0.1$ & $10 \mathrm{~nm}$ & $68.7 \pm 2.4$ & $P \cdot p-10 \mathrm{~nm}$ & $61.2 \pm 0.6$ & B. $s-10 \mathrm{~nm}$ & $54.3 \pm 1.7$ \\
\hline $80 \mathrm{~nm}$ & $22.6 \pm 1.1$ & $80 \mathrm{~nm}$ & $45.1 \pm 6.3$ & P. $p-80 \mathrm{~nm}$ & $33.7 \pm 7.6$ & B. $s-80 \mathrm{~nm}$ & $20.9 \pm 0.3$ \\
\hline $1 \mu \mathrm{m}$ & $7.6 \pm 0.1$ & $1 \mu \mathrm{m}$ & $25.2 \pm 6.6$ & P. $p-1 \mu \mathrm{m}$ & $13.6 \pm 1.6$ & B. $s-1 \mu \mathrm{m}$ & $13.4 \pm 0.6$ \\
\hline
\end{tabular}

Supplementary Table 4. Simulation parameters to the kinetic equation $A=A_{\max }$ $\left(1-\mathrm{e}^{-k t}\right)$ for the adhesion of bacteria with hematite.

\begin{tabular}{|c|c|c|c|}
\hline Bacteria on minerals & $k\left(\mathrm{~s}^{-1}\right)$ & $A_{\max }$ & $R^{2}$ \\
\hline P. putida-10 nm & 1.03 & 0.12 & 0.995 \\
\hline P. putida-80 nm & 0.57 & 0.074 & 0.986 \\
\hline P. putida-1 $\mu \mathrm{m}$ & 0.88 & 0.026 & 0.993 \\
\hline B. subtilis-10 nm & 0.99 & 0.12 & 0.995 \\
\hline B. subtilis $-80 \mathrm{~nm}$ & 0.52 & 0.085 & 0.990 \\
\hline B. subtilis-1 $\mu \mathrm{m}$ & 0.38 & 0.061 & 0.998 \\
\hline
\end{tabular}

Note: $k$ is adsorption rate constant; $A_{\max }$ is the absorbance of amide II at cell saturation coverage.

Supplementary Table 5. Parameters used for the calculation of the interaction energy and secondary energy minima between mineral and bacteria

\begin{tabular}{|c|c|c|c|}
\hline & $A_{1 \mathrm{w} 2}\left(10^{-20} \mathrm{~J}\right)$ & $\Delta G_{d 0}{ }^{A B}\left(\mathrm{~mJ} \mathrm{~m} \mathrm{~m}^{-2}\right)$ & $E_{\text {sem }}\left(10^{-20} \mathrm{~J}\right)$ \\
\hline P. putida-10nm & 0.47 & 10.10 & -9.7 \\
\hline P. putida-80nm & 0.46 & 45.7 & -5.9 \\
\hline P. putida-1 $\mu \mathrm{m}$ & 0.47 & 40.47 & -5.3 \\
\hline B. subtilis-10nm & 0.30 & 4.25 & -8.1 \\
\hline B. subtilis-80nm & 0.29 & 29.63 & -4.7 \\
\hline B. subtilis-1 $1 \mu \mathrm{m}$ & 0.30 & 25.75 & -4.7 \\
\hline
\end{tabular}

Note: $A_{1 \mathrm{w} 2}$ is the combined Hamaker constant $(\mathrm{J}) ; \Delta G_{d 0}{ }^{A B}$ is the Lewis acid/base free energy $\left(\mathrm{J} \mathrm{m}^{-2}\right)$ at minimum separation distance $d_{0} ; E_{\text {sem }}$ is the secondary energy minima. 
spectra deconvolution

\begin{tabular}{|c|c|c|c|c|c|c|c|c|c|}
\hline & $\begin{array}{c}\text { Energy } \\
(\mathrm{eV})\end{array}$ & $P p$ & $\begin{array}{c}P p- \\
10 \mathrm{~nm}\end{array}$ & $\begin{array}{c}P p- \\
80 \mathrm{~nm}\end{array}$ & $\begin{array}{l}P p- \\
1 \mu \mathrm{m}\end{array}$ & $B s$ & $\begin{array}{c}B S- \\
10 \mathrm{~nm}\end{array}$ & $\begin{array}{c}B s- \\
80 \mathrm{~nm}\end{array}$ & $\begin{array}{c}B s- \\
1 \mu \mathrm{m}\end{array}$ \\
\hline \multicolumn{10}{|l|}{$\mathbf{C}$} \\
\hline Aromatic & 285.5 & $8.9 \pm 0.2$ & $10.3 \pm 0.2$ & $8.1 \pm 0.1$ & $8.6 \pm 0.1$ & $5.9 \pm 0.2$ & $8.9 \pm 0.2$ & $8.6 \pm 0.2$ & $8.3 \pm 0.2$ \\
\hline Alkyl & 287.5 & $14.7 \pm 0.2$ & $15.0 \pm 0.3$ & $15.1 \pm 0.2$ & $15.6 \pm 0.2$ & $12.9 \pm 0.3$ & $11.9 \pm 0.2$ & $12.5 \pm 0.3$ & $12.6 \pm 0.2$ \\
\hline Amide/carboxyl & 288.3 & $9.9 \pm 0.4$ & $10.3 \pm 0.5$ & $13.8 \pm 0.3$ & $14.3 \pm 0.3$ & $18.0 \pm 0.4$ & $20.5 \pm 0.4$ & $20.4 \pm 0.4$ & $18.9 \pm 0.4$ \\
\hline Carboxyl & 288.7 & $23.5 \pm 0.3$ & $25.7 \pm 0.4$ & $23.5 \pm 0.3$ & $21.9 \pm 0.3$ & $21.0 \pm 0.4$ & $20.5 \pm 0.4$ & $20.4 \pm 0.4$ & $20.9 \pm 0.4$ \\
\hline \multicolumn{10}{|l|}{$\mathbf{N}$} \\
\hline Rings & 399.4 & $3.2 \pm 0.2$ & $11.3 \pm 0.2$ & $6.6 \pm 0.2$ & $6.8 \pm 0.2$ & $2.6 \pm 0.2$ & $3.3 \pm 0.2$ & $3.2 \pm 0.2$ & $5.2 \pm 0.2$ \\
\hline Amide & 401.0 & $31.8 \pm 0.2$ & $29.3 \pm 0.2$ & $31.9 \pm 0.2$ & $31.5 \pm 0.2$ & $35.5 \pm 0.2$ & $36.1 \pm 0.2$ & $35.4 \pm 0.2$ & $34.4 \pm 0.2$ \\
\hline Pyrrolic & 402.6 & $21.3 \pm 0.2$ & $23.8 \pm 0.2$ & $21.3 \pm 0.2$ & $23.3 \pm 0.2$ & $22.3 \pm 0.2$ & $22.9 \pm 0.2$ & $23.4 \pm 0.2$ & $23.0 \pm 0.2$ \\
\hline Aromatic & 404.0 & $25.6 \pm 0.2$ & $21.3 \pm 0.2$ & $24.6 \pm 0.2$ & $24.7 \pm 0.2$ & $26.8 \pm 0.2$ & $23.8 \pm 0.2$ & $24.7 \pm 0.2$ & $22.7 \pm 0.2$ \\
\hline Heterocyclic & 2474.4 & $22.3 \pm 0.01$ & $22.0 \pm 0.01$ & $21.8 \pm 0.01$ & $21.5 \pm 0.00$ & $24.7 \pm 0.01$ & $23.6 \pm 0.01$ & $24.6 \pm 0.01$ & $24.0 \pm 0.01$ \\
\hline Sulfoxide & 2476.4 & $12.6 \pm 0.01$ & $12.4 \pm 0.01$ & $12.5 \pm 0.00$ & $12.6 \pm 0.01$ & $12.5 \pm 0.01$ & $12.7 \pm 0.01$ & $12.5 \pm 0.01$ & $12.5 \pm 0.01$ \\
\hline Sulfone & 2479.0 & $5.4 \pm 0.00$ & $4.7 \pm 0.00$ & $4.8 \pm 0.00$ & $4.4 \pm 0.00$ & $5.7 \pm 0.01$ & $5.1 \pm 0.01$ & $4.7 \pm 0.01$ & $4.8 \pm 0.01$ \\
\hline Sulfonate & 2481.0 & $2.9 \pm 0.00$ & $3.9 \pm 0.00$ & $3.5 \pm 0.00$ & $3.5 \pm 0.00$ & $2.8 \pm 0.00$ & $3.8 \pm 0.00$ & $3.6 \pm 0.00$ & $3.7 \pm 0.00$ \\
\hline
\end{tabular}




\section{Supplementary References:}

1. M9 minimal medium (standard). Cold Spring Harbor Protocols, 2010(8): pdb.rec12295.

2. Schwertmann, U.; Cornell, R. M. Iron Oxides in the Laboratory. 2000.

3. Hong, Z.; Rong, X.; Cai, P.; Dai, K.; Liang, W.; Chen, W.; Huang, Q. Initial adhesion of Bacillus subtilis on soil minerals as related to their surface properties. Eur. J. Soil Sci. 2012, 63 (4), 457-466.

4. Freyria, F. S.; Bonelli, B.; Tomatis, M.; Ghiazza, M.; Gazzano, E.; Ghigo, D.; Garrone, E.; Fubini, B. Hematite nanoparticles larger than $90 \mathrm{~nm}$ show no sign of toxicity in terms of lactate dehydrogenase release, nitric oxide generation, apoptosis, and comet assay in murine alveolar macrophages and human lung epithelial cells. Chem. Res. Toxicol. 2012, 25 (4), 850-861.

5. Williams, L. B.; Metge, D. W.; Eberl, D. D.; Harvey, R. W.; Turner, A. G.; Prapaipong, P.; Poret-Peterson, A. T. What makes a natural clay antibacterial? Environ. Sci. Technol. 2011, 45 (8), 3768-73.

6. Tovar-Sanchez, A.; Sanudo-Wilhelmy, S. A.; Garcia-Vargas, M.; Weaver, R. S.; Popels, L. C.; Hutchins, D. A. A trace metal clean reagent to remove surface-bound iron from marine phytoplankton. Mar. Chem. 2003, 82 (1-2), 91-99.

7. Schilt, A. A. Analytical Applications of 1,10-phenanthroline and Related Compounds. 1969, 32, 143-160.

8. Lin, D.; Ji, J.; Long, Z.; Yang, K.; Wu, F. The influence of dissolved and surface-bound humic acid on the toxicity of $\mathrm{TiO}_{2}$ nanoparticles to Chlorella $\mathrm{sp}$. Water Res. 2012, 46 (14), 4477-4487.

9. Van Oss, C. J. Hydrophobicity of biosurfaces - Origin, quantitative determination and interaction energies. Colloids Surf., B 1995, 5 (3), 91-110.

10. Van Oss, C. J. Energetics of cell-cell and cell-biopolymer interactions. Cell Biophysics 1989, 14 (1), 1-16.

11. Gregory, J. Approximate expressions for retarded van der waals interaction. $J$. Colloid Interf. Sci. 1981, 83 (1), 138-145.

12. Cai, P.; Huang, Q.; Walker, S. L. Deposition and survival of Escherichia coli O157: H7 on clay minerals in a parallel plate flow system. Environ. Sci.Technol. 2013, 47 (4), 1896-1903.

13. Ge, S.; Agbakpe, M.; Zhang, W.; Kuang, L. Heteroaggregation between PEI-coated magnetic nanoparticles and algae: effect of particle size on algal harvesting efficiency. ACS Appl. Mater. Interfaces 2015, 7 (11), 6102-6108.

14. Sharma, P. K.; Hanumantha Rao, K. Adhesion of Paenibacillus polymyxa on chalcopyrite and pyrite: surface thermodynamics and extended DLVO theory. Colloids Surf., B 2003, 29 (1), 21-38.

15. Hogg, R.; Healy, T. W.; Fuerstenau, D. W. Mutual Coagulation of Colloid Dispersions. Transactions of the Faraday Society 1966, 62 (522P), 1638-1651.

16. Bos, R.; van der Mei, H. C.; Busscher, H. J. Physico-chemistry of initial microbial adhesive interactions-its mechanisms and methods for study. FEMS 
Microbiol Rev. 1999, 23 (2), 179-230.

17. Zhang, W.; Rittmann, B.; Chen, Y. Size effects on adsorption of hematite nanoparticles on E. coli cells. Environ. Sci. Technol. 2011, 45 (6), 2172-2178.

18. Elzinga, E.J., Huang, J.-H., Chorover, J., Kretzschmar, R. ATR-FTIR spectroscopy study of the influence of $\mathrm{pH}$ and contact time on the adhesion of Shewanella putrefaciens bacterial cells to the surface of hematite. Environ. Sci. Technol. 2012, 46(23): 12848-12855.

19. Yan, W., Wang, H., Jing, C. Adhesion of Shewanella oneidensis MR-1 to goethite: A two-dimensional correlation spectroscopic study. Environ. Sci. Technol. 2016, 50(8): 4343-4349.

20. Young, A. G.; McQuillan, A. J. Adsorption/desorption kinetics from ATR-IR spectroscopy. Aqueous oxalic acid on anatase $\mathrm{TiO}_{2}$. Langmuir 2009, 25 (6), 3538-3548.

21. Ana, D.V., Saenz-Navajas, M.P., María José, A.C.A., Bernhard, L. Detection of albumin unfolding preceding proteolysis using Fourier transform infrared spectroscopy and chemometric data analysis. Anal. Chem. 2006, 78(10): 3257.

22. Jia, Q., Wang, N.N., Yu, Z.W. An insight into sequential order in two-dimensional correlation spectroscopy. Appl. Spectrosc. 2009, 63(3): 344.

23. Alleon, J.; Bernard, S.; Guillou, C. L.; Daval, D.; Skouri-Panet, F.; Pont, S.; Delbes, L.; Robert, F. Early entombment within silica minimizes the molecular degradation of microorganisms during advanced diagenesis. Chem. Geol. 2016, 437, 98-108.

24. Schumacher, M.; Christl, I.; Scheinost, A. C.; Jacobsen, C.; Kretzschmar, R. Chemical Heterogeneity of Organic Soil Colloids Investigated by Scanning Transmission X-ray Microscopy and C-1s NEXAFS Microspectroscopy. Environ. Sci. Technol. 2005, 39 (23), 9094-9100.

25. Singh, B.; Fang, Y.; Cowie, B. C. C.; Thomsen, L. NEXAFS and XPS characterisation of carbon functional groups of fresh and aged biochars. Org. Geochem. 2014, 77, 1-10.

26. Urquhart, S. G.; Ade, H.; Rafailovich, M.; Sokolov, J. S.; Zhang, Y. Chemical and vibronic effects in the high-resolution near-edge $\mathrm{X}$-ray absorption fine structure spectra of polystyrene isotopomers. Chem. Phys. Lett. 2000, 322 (5), 412-418.

27. Cody; D., G.; Botto; E., R.; Ade; H.; Behal; S.; Disko; M.; Wirick; S. Inner-shell spectroscopy and imaging of a subbituminous coal: in-situ analysis of organic and inorganic microstructure using $\mathrm{C}(1 \mathrm{~s})-, \mathrm{Ca}(2 \mathrm{p})-$, and $\mathrm{Cl}(2 \mathrm{~s})-\mathrm{NEXAFS}$. Energ. Fuel. 1995, 9, 525-533.

28. Gillespie, A. W.; Walley, F. L.; Farrell, R. E.; Leinweber, P.; Eckhardt, K.-U.; Regier, T. Z.; Blyth, R. I. R. XANES and Pyrolysis-FIMS Evidence of Organic Matter Composition in a Hummocky Landscape. Soil Sci. Soc. Am. J. 2011, 75 (5), 1741-1755.

29. Manceau, A.; Nagy, K. L. Quantitative analysis of sulfur functional groups in natural organic matter by XANES spectroscopy. Geochim. Cosmochim. Ac. 2012, 99, 206-223. 